\title{
Formation of Tissue-Resident $\mathrm{CD}^{+}$T-Cell Memory
}

\author{
Feline E. Dijkgraaf, Lianne Kok, and Ton N.M. Schumacher \\ Division of Molecular Oncology and Immunology, Oncode Institute, The Netherlands Cancer Institute, \\ 1066 Amsterdam, the Netherlands \\ Correspondence: t.schumacher@nki.nl
}

\begin{abstract}
Resident memory $\mathrm{CD}^{+} \mathrm{T}(\mathrm{Trm})$ cells permanently reside in nonlymphoid tissues where they act as a first line of defense against recurrent pathogens. How and when antigen-inexperienced $\mathrm{CD}^{+} \mathrm{T}$ cells differentiate into Trm has been a topic of major interest, as knowledge on how to steer this process may be exploited in the development of vaccines and anticancer therapies. Here, we first review the current understanding of the early signals that $\mathrm{CD} 8{ }^{+} \mathrm{T}$ cells receive before they have entered the tissue and that govern their capacity to develop into tissue-resident memory T cells. Subsequently, we discuss the tissue-derived factors that promote Trm maturation in situ. Combined, these data sketch a model in which a subset of responding $\mathrm{T}$ cells develops a heightened capacity to respond to local cues present in the tissue microenvironment, which thereby imprints their ability to contribute to the tissueresident memory $\mathrm{CD}^{+} \mathrm{T}$-cell pool that provide local control against pathogens.
\end{abstract}

\section{CHARACTERISTICS OF TISSUE-RESIDENT MEMORY CD8 ${ }^{+}$T CELLS}

U pon local infection of a tissue site, dendritic cells (DCs) that have taken up pathogenderived antigens migrate to the draining secondary lymphoid organs (SLOs) where they interact with antigen-specific naive $\mathrm{CD} 8^{+} \mathrm{T}$ cells. During this encounter, DCs present peptide major histocompatibility complexes (pMHCs) to the $\mathrm{T}$-cell receptors (TCRs) on naive T cells, while also providing costimulatory ligands and cytokine signals. As a consequence of these signals, $\mathrm{CD}^{+} \mathrm{T}$ cells specific for an MHC class I-presented, pathogen-derived antigen, undergo rapid clonal expansion and differentiate into effector phase T cells that leave the SLOs to enter the blood. Part of the effector phase $\mathrm{CD}^{+} \mathrm{T}$-cell population will subsequently enter the affected body site to contribute to pathogen clearance, both by the direct lysis of infected cells, and by the antiviral and antibacterial activities of interferon $\gamma($ IFN- $\gamma)$, and tumor necrosis factor $\alpha$ (TNF- $\alpha$ ) that effector phase $\mathrm{T}$ cells secrete upon antigen encounter. Following pathogen clearance, $\sim 90 \%-95 \%$ of the effector phase $T$ cells die due to apoptosis (Williams and Bevan 2007), leaving behind a small population of long-lived memory $\mathrm{CD}^{+} \mathrm{T}$ cells. These memory $\mathrm{CD}^{+} \mathrm{T}$ cells persist for many years in the body to provide rapid protection in case of reinfection.

Traditionally, two major subsets of memory $\mathrm{CD}^{+} \mathrm{T}$ cells, referred to as central memory

Editors: David Masopust and Rafi Ahmed

Additional Perspectives on T-Cell Memory available at www.cshperspectives.org

Copyright (C) 2021 Cold Spring Harbor Laboratory Press; all rights reserved; doi: 10.1101/cshperspect.a038117

Cite this article as Cold Spring Harb Perspect Biol 2021;13:a038117 
F.E. Dijkgraaf et al.

$\mathrm{T}(\mathrm{Tcm})$ cells and effector memory $\mathrm{T}$ (Tem) cells, have been distinguished on the basis of their trafficking abilities. Similar to naive T cells, Tcm cells show cell surface expression of C-C chemokine receptor type 7 (CCR7) and L-selectin (CD62L) that allow for entry into lymphoid tissues. Tcm cells can be found circulating in blood, efferent lymph, and SLOs. In contrast to Tcm cells, Tem cells lack expression of CCR7 and CD62L, and this memory $\mathrm{T}$-cell population primarily recirculates in blood and peripheral tissues. Work over the past two decades has however identified a third memory $\mathrm{CD}^{+}$T-cell subset that permanently resides at sites of previous pathogen infection. Such tissue-resident memory $\mathrm{CD}^{+} \mathrm{T}$ (Trm) cells have now been described in a series of nonlymphoid tissues in mice and humans, including the skin, lung, intestines, vaginal mucosa, and brain (Gebhardt et al. 2018; Szabo et al. 2019). In addition, T-cell populations with Trm-like characteristics have been identified in mouse models of solid cancers and in human malignancies (Amsen et al. 2018; Park et al. 2019b). Trm cells are generally characterized by cell-surface expression of CD69, a molecule that is transiently expressed on recently activated $\mathrm{T}$ cells at other body sites, but that shows sustained expression on Trm cells. CD69 binds to and antagonizes cell surface expression of the G-coupled protein sphingosine-1-phosphate receptor 1 (S1PR1) (Bankovich et al. 2010). As the sensing of $\mathrm{S} 1 \mathrm{P}$, which is present in high concentrations in blood and lymph but low in tissues, by S1PR1 is a major factor driving T-cell egress, regulation of S1PR1 expression by CD69 forms a mechanism to achieve tissue-residency. Next to the constitutive expression of CD69, Trm cells express a core "tissue-residency" transcriptional profile that is shared between tissue-resident $\mathrm{CD}^{+} \mathrm{T}$ cells at different body sites, and that distinguishes these cells from circulating $\mathrm{CD}^{+}$T-cell subsets (Mackay et al. 2013; Kumar et al. 2017). Notably, the core transcriptional signature of human $\mathrm{CD} 9^{+}$Trm shows a substantial overlap with that of murine $\mathrm{CD}^{+}$Trm cells generated upon herpes simplex virus-1 or acute lymphocytic choriomeningitis virus infection (Kumar et al. 2017), supporting the validity of mouse models to understand human Trm cell biology. Next to the
CD69-S1PR1 axis, two other pathways have been shown to influence the capacity of Trm cells to remain tissue resident. Specifically, CD69 ${ }^{+}$ Trm cells in epithelial tissues (e.g., skin epidermis and brain epithelium) often express the $\alpha \mathrm{E}$ subunit (CD103) of the $\alpha E \beta 7$ integrin. CD103 is an adhesion molecule that interacts with E-cadherin expressed on epithelial cells, thereby contributing to Trm retention (El-Asady et al. 2005; Mackay et al. 2013). In addition to this receptor-ligand pair, a sizable fraction of $\mathrm{CD} 9^{+} \mathrm{CD} 103^{+}$Trm cells also express the very late antigen-1 integrin (CD49a), which binds collagen type IV present in basement membranes (Ray et al. 2004; Gebhardt et al. 2009; Kumar et al. 2017). Next to CD69, CD103, and CD49a, other molecules have been described to distinguish Trm cells from circulating memory T-cell subsets, including CXCR3, CXCR6, and CD101 (Fernandez-Ruiz et al. 2016; Kumar et al. 2017; Zaid et al. 2017). It is important to note that the presence of any of these markers on $\mathrm{CD}^{+}$memory T cells, including CD69 or CD103, is insufficient to unambiguously classify $\mathrm{CD}^{+} \mathrm{T}$ cells as tissue resident (Mackay et al. 2015; Steinert et al. 2015; Beura et al. 2018a). Conversely, absence of any of these molecules does not necessarily indicate a lack of residency (Bergsbaken and Bevan 2015; Steinert et al. 2015). In the majority of studies, $\mathrm{CD}^{+}$Trm cells are defined as $\mathrm{CD} 9^{+} \mathrm{CD} 103^{+}$memory $\mathrm{T}$ cells at tissue sites, and we will also use this definition. However, it is important to keep in mind that additional Trm cell subsets do exist, and that these may show subtle differences with respect to both differentiation pathways and functional characteristics.

\section{PROTECTIVE FUNCTION OF RESIDENT MEMORY T CELLS}

Once established at local sites, Trm cells play a key role in protecting tissue from reinfection. Intravital and ex vivo imaging studies in murine skin (Ariotti et al. 2012; Zaid et al. 2014), liver (Fernandez-Ruiz et al. 2016; McNamara et al. 2017), vaginal mucosa (Beura et al. 2018b), and also in human skin (Dijkgraaf et al. 2019) have shown that in the absence of infection, $\mathrm{CD}^{+}$Trm cells actively patrol their surround- 
ings. This tissue patrol allows Trm cells to efficiently identify antigen-positive cells at the moment reinfection occurs (Ariotti et al. 2012). In mice, Trm cells have been shown to provide superior protection against local reinfection with acute lymphocytic choriomeningitis virus (Hofmann and Pircher 2011), oral Listeria monocytogenes (Sheridan et al. 2014), vaccinia virus (Jiang et al. 2012), and herpes simplex virus-1 (Gebhardt et al. 2009; Ariotti et al. 2012; Mackay et al. 2012) as compared to circulating memory $\mathrm{T}$ cells. Consistent with expectations, such protection has been shown to correlate with local Trm-cell density in mouse models (Park et al. 2018), providing a compelling argument to try to boost local Trm cell numbers by vaccination. Furthermore, in patients with herpes simplex virus- 2 infection, the number of $\mathrm{CD}^{+}{ }^{+} \mathrm{Trm}$ cells positively correlated with viral clearance in the vaginal mucosa (Schiffer et al. 2010, 2013, 2018), also suggesting that in human tissues Trm cell densities determine their protective effect. The residency of Trm cells in human tissue, and also their protective capacity, has been shown in patients with cutaneous T-cell lymphoma that received low-dose alemtuzumab (anti-CD52) treatment. Anti-CD52 treatment selectively depletes circulating $\mathrm{T}$ cells while sparing $\mathrm{T}$ cells in skin, and the preservation of the cutaneous T-cell pool was shown to be associated with local protection (Clark et al. 2012). Next to protection from viral and bacterial reinfections, emerging evidence also indicates a beneficial role for $\mathrm{CD} 8^{+}$ Trm cells in human solid cancers (as reviewed by Amsen et al. 2018; Park et al. 2019b). In mice, preformed tumor antigen-specific Trm cells and Trm cells that developed during tumorigenesis were shown to control tumor growth, also in the absence of circulating memory T cells (Park et al. 2019a). In humans, $\mathrm{CD}^{+} 9^{+} \mathrm{CD} 103^{+} \mathrm{CD}^{+}$tumor-infiltrating lymphocytes (TILs) have been observed in several solid cancers (Amsen et al. 2018; Park et al. 2019b), and CD $103^{+} \mathrm{CD}^{+}$TIL densities, as inferred by phenotypic or transcriptional analysis, have been associated with improved patient survival in different cancer types including melanoma (Edwards et al. 2018), lung (Djenidi et al. 2015; Ganesan et al. 2017), bladder (Wang et al. 2015), ovarian (Webb et al.
2014), endometrial (Workel et al. 2016), cervical (Komdeur et al. 2017), breast (Savas et al. 2018), and colorectal cancers (Hu et al. 2019). Interestingly, single-cell profiling studies in various cancers have demonstrated that $\mathrm{CD} 103^{+} \mathrm{CD} 8^{+}$TILs, or in one case $\mathrm{CD} 39^{+} \mathrm{CD} 103^{+} \mathrm{CD}^{+}$TILs, often display a dysfunctional transcriptional state, characterized by high expression of coinhibitory receptors such as PD-1, TIM-3, and Lag-3 (Ganesan et al. 2017; Duhen et al. 2018; Savas et al. 2018), a process thought to be driven by tumorantigen recognition (Li et al. 2019b). Although these data suggest a central role for Trm cells in cancer biology and cancer immunotherapy, it is important to bear in mind that expression of Trm cell-associated markers does not necessarily imply the presence of true resident memory T cells. Specifically, as CD69 and CD103 expression are both induced by TCR triggering (Wakim et al. 2010; Khan et al. 2016), the presence of these molecules may also indicate recent antigen encounter (Mackay et al. 2013). In addition, CD69 expression is reported to be induced in oxygen-deprived milieus, as one may expect to be present in larger tumors (Labiano et al. 2017). Thus, an appropriate level of care is required when aiming to translate findings on Trm cells that arise after local viral infection to tumor-resident $\mathrm{T}$ cells, as the mechanisms that control their formation and function may differ.

Trm cells exert their protective effect by both direct and indirect mechanisms. Direct killing of cognate antigen-expressing target cells by Trm cells can occur by the secretion of cytotoxic molecules such as granzyme B and perforin (Wakim et al. 2010; Steinbach et al. 2016). Importantly, activated Trm cells also provide tissue protection through indirect means by the secretion of cytokines and the resultant activation and recruitment of other immune cell types. Specifically, transcriptional studies have shown that upon cognate antigen triggering, skin Trm cells rapidly (within hours) instruct the surrounding tissue to express molecules involved in broad-spectrum host defense. This "tissue conditioning" is to a large extent dependent on IFN- $\gamma$ and also provides protection against antigenically unrelated pathogens (Ariotti et al. 2014), in essence forming a reverse link between adaptive and innate immu- 
F.E. Dijkgraaf et al.

nity. Furthermore, IFN- $\gamma$ production by activated Trm cells in the vaginal mucosa leads to the rapid recruitment (within $12 \mathrm{~h}$ ) of circulatory memory T cells and B cells (Schenkel et al. 2013, 2014). In addition, when activated by antigen, Trm cells produce TNF- $\alpha$ and interleukin (IL)-2, thereby inducing maturation of local DCs and activation of natural killer cells (NKs), respectively (Schenkel et al. 2014). Moreover, Trm cells contribute to secondary Trm cell pools by local proliferation after reinfections (Park et al. 2018). Next to their role at the tissue site, a fraction of activated Trm cells in the vaginal mucosa and skin has been shown to leave the primary tissue site and populate the draining lymph nodes (dLNs) upon reinfection, potentially to contribute to protection in the dLN and/or to repopulate the downstream nonlymphoid tissue after reinfection (Beura et al. 2018a). Together, these data sketch a role for Trm cells as tissue sentinels that rapidly alarm their surroundings when antigen is encountered, to both establish local protection and to contribute to secondary Trm cell populations. In view of the role that Trm cells play in preventing or limiting local disease, an understanding of the signals that determine Trm cell formation is of interest from both a fundamental and therapeutic perspective.

\section{FORMATION OF TISSUE-RESIDENT

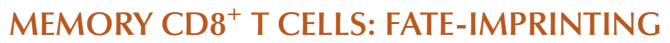 SIGNALS PRIOR TO TISSUE ENTRY}

Whereas a number of studies have demonstrated the importance of tissue-derived factors in Trm cell formation, more recent work has started to highlight the contribution of signals that $\mathrm{CD}^{+}$ $\mathrm{T}$ cells receive already prior to tissue entry and that help control Trm cell fate. Below, we will discuss such signals and the contribution of these signals during the different phases in the development of an antigen-specific $\mathrm{CD}^{+} \mathrm{T}$-cell response (see also Fig. 1).

\section{Preconditioning at the Naive Cell Stage}

As demonstrated by single-cell lineage-tracing studies using cellular barcoding or congenic markers, individual naive $\mathrm{CD}^{+} \mathrm{T}$ cells are ca- pable of producing phenotypically and functionally distinct effector phase T cells (Stemberger et al. 2007; Gerlach et al. 2010, 2011, 2013; Buchholz et al. 2013). Likewise, individual naive $\mathrm{CD} 8^{+} \mathrm{T}$ cells yield both Tem and Tcm cells as progeny. These data demonstrate that commitment to a short-term effector or long-term memory cell fate is not fully determined at the naive cell stage. In line with these data, sequencing of the Tcrbv gene encoding the TCR- $\beta$ CDR3 region of $\mathrm{CD}^{+} \mathrm{T}$ cells demonstrated that every abundant Trm cell clone present in the skin after local immunization was also detected in the LNs (Gaide et al. 2015). Thus, as is the case for Tem and Tcm cells, Trm and Tcm cells share a common precursor in the naive T-cell pool. Furthermore, analysis of the TCR- $\alpha \beta$ repertoire of antigen-specific $\mathrm{T}$ cells isolated from human lung tissue demonstrated a substantial overlap between the $\mathrm{CD} 9^{+} \mathrm{CD} 103^{+}$Trm cell pool and both the $\mathrm{CD} 9^{+} \mathrm{CD} 103^{-}$and $\mathrm{CD}^{-} 9^{-} \mathrm{CD} 103^{-}$ memory T-cell pool. As the latter population is generally considered to be a circulating subset (Watanabe et al. 2015; Pallett et al. 2017; Pizzolla et al. 2018), these data suggest that human Trm cells also share a common precursor with circulating memory $\mathrm{T}$ cells.

Whereas these data establish that individual naive $\mathrm{T}$ cells are not fully committed to a particular memory T-cell fate, a recent study by Mani et al. has provided the first evidence that naive $\mathrm{T}$ cells can be conditioned to preferentially yield epithelial Trm cells as output (Mani et al. 2019). Prior work demonstrated a requirement for active transforming growth factor $\beta$ (TGF- $\beta$ ) to induce the CD103 expression that contributes to tissue-residency of $\mathrm{CD}^{+} \mathrm{T}$ cells (El-Asady et al. 2005; Mackay et al. 2013). Activation of TGF- $\beta$ requires release from the latency-associated protein (LAP), and this release can be mediated by the binding of $\alpha \mathrm{V}$-integrins to the TGF- $\beta$-LAP complex (Travis and Sheppard 2014). Making use of mice bearing DCs that lack $\alpha \mathrm{V}$-integrin expression, Mani et al. showed that efficient formation of epithelial Trm cells depends on migratory $\alpha \mathrm{V}$-integrin ${ }^{+} \mathrm{DCs}$ that present active TGF- $\beta$ to resting naive $\mathrm{CD}^{+}$ $\mathrm{T}$ cells during noncognate interactions in the dLN. This interaction was shown to introduce 

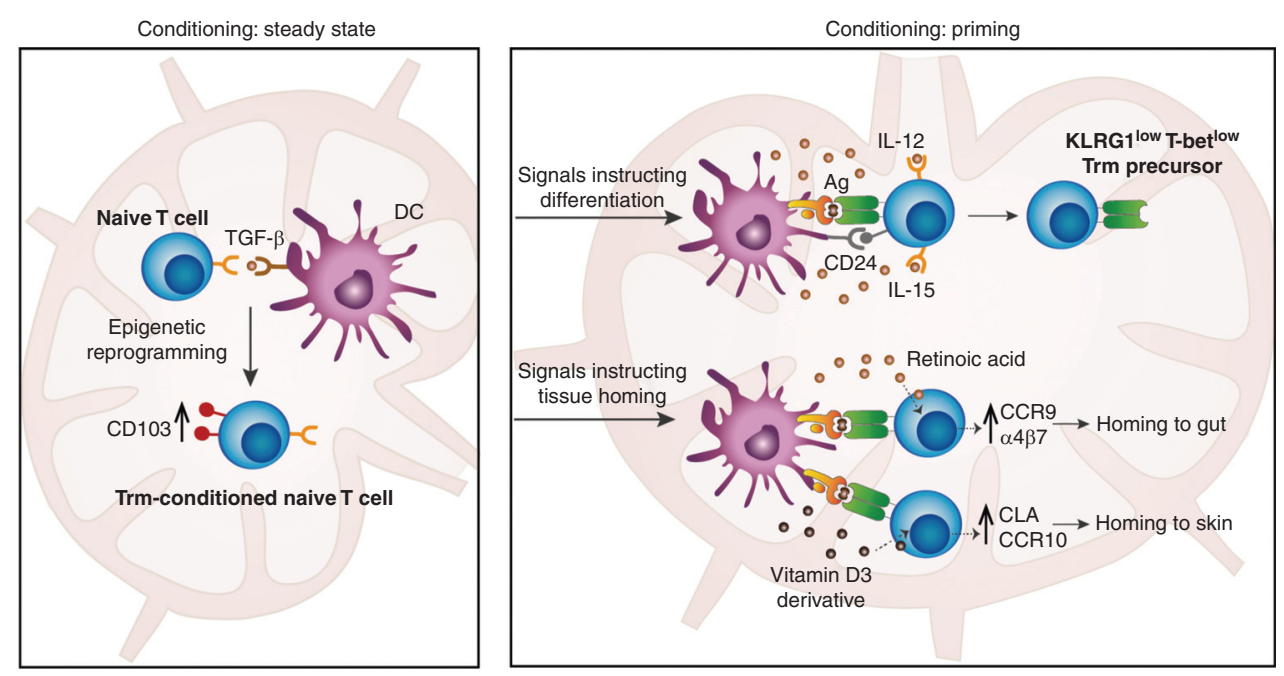

Figure 1. Trm cell conditioning in lymphoid tissues by dendritic cells (DCs). DCs are critical players in Trm cell fate conditioning of naive T cells. (Left panel) In the absence of infection, $\alpha \mathrm{V}^{+}$migratory DCs present active transforming growth factor $\beta$ (TGF- $\beta$ ) that promotes epigenetic modifications in naive T cells and poises them for epithelial (i.e., $\mathrm{CD}_{103^{+}}$) Trm cell fate. (Right panel) In case of infection, certain signals that DCs provide to naive $\mathrm{T}$ cells during activation can increase their capacity to form Trm cells (i.e., yielding effector phase T cells with low expression of killer cell lectin-like receptor G1 [KLRG1] and transcription factor T-bet), such as antigen crosspresentation, costimulation via CD24, and cytokines such as IL-12 and IL-15. In addition, DCs may process and present metabolites to induce expression of lymphocyte homing molecules (e.g., CCR9 and $\alpha 4 \beta 7$ ) on activated $\mathrm{T}$ cells, thereby instructing them to migrate to specific tissue sites.

epigenetic modifications at transcription factor (TF) binding sites (e.g., of RUNX3 and KLF family members; see also Box 1 ) in genes that are implicated in Trm cell formation, such as Itgae (encoding CD103), Ccr8, and S1pr5 (Mani et al. 2019). Together, these data indicate that cell contact-dependent delivery of active TGF- $\beta$ to individual naive $\mathrm{CD} 8^{+} \mathrm{T}$ cells introduces heterogeneity within the naive T-cell pool and poises cells for epithelial Trm cell fate.

\section{Signals during T-Cell Priming}

During the initiation of the $\mathrm{CD} 8^{+} \mathrm{T}$-cell response, $\mathrm{T}$ cells get activated and shift to a "primed" state upon interaction with antigenpresenting DCs in the SLOs. The type, duration, and severity of the infection determine the amount of antigen, and also the nature and magnitude of costimulatory signals and cytokine signals the DC provides to the CD8 ${ }^{+} \mathrm{T}$ cell (Kaech and Cui 2012). Together, these signals shape the magnitude and kinetics of the antigen-specific $\mathrm{CD}^{+} \mathrm{T}$-cell response, and also the composition of the effector and memory T-cell pools (Zehn et al. 2009; Kaech and Cui 2012). Whereas it is currently unclear how the signals provided during priming exactly impact Trm cell fate decisions, several reports are starting to provide insight on this matter.

As mentioned above, single-cell lineagetracing studies have demonstrated that one naive $\mathrm{CD}^{+} \mathrm{T}$ cell gives rise to both effector and memory T-cell subsets. However, at the same time, it has become apparent that individual naive $\mathrm{CD}^{+} \mathrm{T}$ cells bearing the same TCR differ in type of output and the number of progeny they produce (Stemberger et al. 2007; Gerlach et al. 2010, 2011, 2013; Buchholz et al. 2013). In addition to this TCR-independent variability in cellular output, several studies have shown a relationship between the strength of antigenic stimulation and the ability to yield different memory T-cell subsets. Specifically, low-affinity 
F.E. Dijkgraaf et al.

\section{BOX 1. TRANSCRIPTION FACTORS INVOLVED IN TRM FORMATION}

In mice, the transcription factors (TFs) that have been shown to either positively or negatively influence Trm cell formation include Eomesodermin (Eomes), T-bet, KLF2, RUNX3, Notch, Nr4a1, aryl hydrocarbon receptor (Ahr), Bhlhe4, Blimp-1, and the Blimp-1 homologue Hobit.

Whereas the formation of circulatory memory T cells depends on Eomes, Trm cell differentiation in situ requires a complete shutdown of Eomes expression (Mackay et al. 2015). Likewise, high T-bet expression on responding T cells in the tissue is a negative regulator of Trm cell formation (Laidlaw et al. 2014); however, skin Trm cells do require low transcript levels of T-bet for the induction of CD122 to sense IL-15 (Mackay et al. 2015). KLF2 drives S1PR1 expression in circulating memory T cells to provide access to the blood or lymph (Bai et al. 2007). Reduced expression of KLF2 and its target S1PR1 is a prerequisite for Trm cell formation, as shown by the impaired skin Trm cell formation upon forced expression of these molecules in effector phase T cells (Skon et al. 2013). RUNX3 acts as a central promotor of resident memory $\mathrm{T}$-cell fate in the small intestine and kidney, by supporting the expression of tissue-residency genes (i.e., CD69, Nr4a 1) and suppression of genes involved in tissue egress and recirculation (i.e., S1pr1, Klf2) (Milner et al. 2017). Notch directly regulates CD103 transcript levels in lung Trm cells and has been implied in Trm cell maintenance through the regulation of metabolic processes (Hombrink et al. 2016). Nr4a1 is expressed in Trm cells, but not in circulatory memory T cells, and has been proposed to be involved in residency of Trm cells in the small intestine and liver. However, as downstream targets of $\mathrm{Nr} 4 \mathrm{a} 1$ have not been identified to date, the precise working mechanism remains to be elucidated (Boddupalli et al. 2016; Li et al. 2016). The Aryl hydrocarbon receptor Ahr is highly expressed in human skin Trm cells and was shown to be necessary for maintenance of Trm cells in murine skin (Zaid et al. 2014; Li et al. 2016). Ahr ligands are environmentally derived small molecules (e.g., diet, microorganisms) (Gutierrez-Vazquez and Quintana 2018). Ahr expression is required for homeostasis of $\gamma \delta$ T cells in the skin (Kadow et al. 2011) and CD8 $\alpha \alpha^{+}$intraepithelial intestinal lymphocytes (Li et al. 2011), suggesting that similar pathways drive environmental adaptation of Trm cells and tissue-resident innate immune cells. Bhlhe4 is critical for the survival and function of lung Trm cells and CD8 ${ }^{+}$TILs. Bhlhe4 induces expression of multiple mitochondrial genes thereby supporting oxidative phosphorylation and mitochondrial fitness. These processes promote acetylation of genes involved in tissue-residency (e.g., Itgae [encoding CD103], Runx3) and effector function (e.g., Ifng, GzmB) (Li et al. 2019a). Blimp-1, rather than Hobit, is required for Trm cell formation in lung tissue (Behr et al. 2019), whereas both TFs are required for the formation of Trm cells in the skin, liver, kidney, and small intestine (Mackay et al. 2016). Both Hobit and Blimp-1 directly bind the Klf2, S1 pr1, and C Cr7 loci, thereby regulating tissueresidency programs (Behr et al. 2018). Interestingly, other tissue-resident immune cells such as natural killer T lymphocytes (NKTs) also show elevated Hobit expression (van Gisbergen et al. 2012), suggesting that this TF is a central regulator of tissue-residency. However, Hobit transcript levels are low in $\mathrm{CD} 9^{+}$Trm cells isolated from human lung (Kumar et al. 2017), and Hobit expression has also been observed in effector T cells and effector memory T cells isolated from human peripheral blood (Vieira Braga et al. 2015), suggesting that Hobit may play a different role in human Trm cells.

TCR interactions have been shown to preferentially result in the formation of Tcm cells, whereas high-affinity TCR interactions generally favor the formation of Tem cells with an enhanced expression of molecules associated with terminal differentiation (i.e., killer cell lectin-like receptor G1 [KLRG1; Joshi et al. 2007] and CX3C chemokine receptor 1 [CX3CR1; Smith-Garvin et al. 2010; Böttcher et al. 2015; Gerlach et al.
2016; Fiege et al. 2019]). Recent studies also suggest a role for TCR signal strength in the formation of Trm cells, although the results in part appear contradictory. First, Trm cells formed in the brain and kidneys after local persistent mouse polyoma virus $(\mathrm{MPyV})$ infection showed a \pm 20 -fold higher affinity than circulating memory $\mathrm{T}$ cells, indicating that increased TCR signal strength can positively correlate 
with the capacity to yield Trm cells (Frost et al. 2015). In line with these data, $\mathrm{CD}^{+} \mathrm{T}$ cells bearing a high-affinity TCR showed improved tissue entry and local persistence in the brain as compared to low-affinity $\mathrm{T}$ cells in mouse models of chronic Toxoplasma gondii infection (Sanecka et al. 2018). In contrast, systemic infection with $\mathrm{MPyV}$ strains expressing variants of a subdominant $\mathrm{CD} 8^{+} \mathrm{T}$-cell epitope was used to show that weak TCR stimulation yielded increased numbers of $\mathrm{CD}_{103^{-}}$Trm cells and functionally superior $\mathrm{CD}_{103^{-}}$Trm cells in the brain as compared to strong TCR stimulation (Maru et al. 2017). In line with the latter observations, a recent study in which Trm cell formation was assessed after infection with influenza A strains bearing either a high-affinity cognate epitope or low-affinity variants showed that recognition of low-affinity antigen by $\mathrm{CD}^{+} \mathrm{T}$ cells favored formation of lung Trm cells relative to systemic $\mathrm{CD}^{+} \mathrm{T}$ memory, as compared to high-affinity interactions (Fiege et al. 2019). Interestingly, this preferential Trm cell formation by weakly stimulated $\mathrm{CD}^{+} \mathrm{T}$ cells was also observed at the distant vaginal mucosa tissue that lacked cognate antigen, suggesting that the antigenic signals provided during priming are relevant for Trm cell formation irrespective of possible additional effects at the tissue site. Together, these data support the notion that early antigenic stimulation can impact Trm cell differentiation. Notably, the TCR- $\alpha \beta$ repertoire of Trm cells in human lung tissue specific to the same epitope was shown to be clonally diverse (Pizzolla et al. 2018). Whereas it cannot be excluded that these different TCRs have a similar affinity for antigen, these data are consistent with the possibility that a range of TCR signal strengths can lead to Trm cell formation in humans.

With respect to other signals that may influence Trm cell formation, a study by Iborra et al. has highlighted that the type of antigen-presenting DCs that T cells encounter during priming determines the efficiency of Trm cell formation in murine skin and lung (Iborra et al. 2016). In this work, mice lacking DCs capable of antigen cross-presentation (i.e., DNGR1- or Batf3-deficient) showed impaired Trm cell formation after vaccinia virus or influenza A infection, while systemic memory T-cell subsets were unaffected. Effector phase $\mathrm{CD}^{+} \mathrm{T}$ cells raised in crosspriming deficient mice egress the dLN earlier than responding $\mathrm{T}$ cells in wild-type animals, and populate the skin with enhanced expression of terminal differentiation markers (i.e., KLRG1 and the TF T-bet; see Box 1). Cross-priming $\mathrm{CD}_{103}{ }^{+}$and $\mathrm{CD} 8 \alpha^{+}$DCs were shown to prolong antigen presentation, provide costimulation via CD24, and secrete IL-12 and IL-15. These signals transiently induce high levels of T-bet in $\mathrm{CD}^{+}{ }^{+} \mathrm{T}$ cells in the dLN and expression of the downstream target CXCR3, causing the cells to populate the tissue as $\mathrm{KLRG1}^{-}$and T-bet ${ }^{\text {low }}$ effector phase T cells (Iborra et al. 2016; Enamorado et al. 2018), which were shown to possess an increased ability to generate Trm cells (Mackay et al. 2013).

For Trm cells to form, entry of effector phase $\mathrm{T}$ cells into peripheral tissues is an obvious requirement, and regulation of the capacity to extravasate can therefore comprise a means to control Trm cell formation. Instructions for lymphocyte homing can be provided by DCs during priming and are influenced by the location of the tissue-associated SLOs. For example, priming within the mesenteric LN induces $\alpha 4 \beta 7$ integrin and CCR9 expression on T cells, thereby allowing their homing to the gut, whereas priming in the inguinal LN induces expression of the cutaneous lymphocyte-associated antigen (CLA), which contributes to homing to the skin (Masopust et al. 2010; Masopust and Schenkel 2013; Sheridan et al. 2014). Notably, gut homing by effector phase $\mathrm{T}$ cells after systemic lymphocytic choriomeningitis virus infection was shown to be instructed in the spleen (Masopust et al. 2010), demonstrating that homing instructions are not absolute, and also providing a mechanistic explanation for the formation of local Trm cells after systemic infections. Interestingly, $\alpha 4 \beta 7$ and CCR9 expression is induced by the vitamin A derivative retinoic acid (RA) that is produced by antigen-presenting DCs in gut-associated SLOs (Iwata et al. 2004). In addition, DCs in skin-associated SLOs process ultraviolet-induced vitamin $\mathrm{D}$ and present the active form (i.e., $1,25(\mathrm{OH})_{2} \mathrm{D} 3$ ) to activated $\mathrm{T}$ cells, thereby inducing expression of the skin-homing 
F.E. Dijkgraaf et al.

receptor CCR10 (Sigmundsdottir et al. 2007; Sigmundsdottir and Butcher 2008), providing another example of metabolite-induced tissue tropism.

Interestingly, a study by Sowell et al. has described a role for the mammalian target of rapamycin kinase (mTOR) signaling pathway in Trm cell homing (Sowell et al. 2014). In this work, inhibition of the mTOR signaling pathway (i.e., through knockdown or treatment with rapamycin) impaired migration of effector phase $\mathrm{T}$ cells to the gut and vaginal mucosa, while the number of circulating effector phase $\mathrm{T}$ cells was enhanced (Sowell et al. 2014). As the effector phase $\mathrm{T}$ cells in the gut showed decreased levels of $\beta 7$ and CCR9 expression upon mTOR pathway inhibition, and the metabolite RA can induce components of the mTOR pathway (Lal et al. 2005), the authors propose that mTOR-induced expression of homing molecules plays a key role in Trm cell formation.

Heterogeneity within the Effector T-Cell Pool: Evidence for a Trm Cell Precursor?

As established many years ago, the pool of effector phase $\mathrm{T}$ cells that arises following $\mathrm{T}$-cell priming shows heterogeneity with respect to its capacity to develop into memory T cells. Specifically, within the effector phase T-cell pool two subsets, terminal effector $\mathrm{T}$ (TE) cells, and memory precursors (MPs), can be distinguished. TE cells show cell-surface expression of KLRG1 but lack expression of CD127 (i.e., the IL-7 receptor $\alpha$ chain [IL-7R $\alpha])$. TE cells generally undergo apoptosis after clearance of the infection and hence exhibit a low potential to persist long term (Joshi et al. 2007). Conversely, MPs express very low levels of KLRG1 but do express IL-7R $\alpha$ and preferentially give rise to long-lived memory $\mathrm{T}$ cells (i.e., Tem and Tcm cells) (Kaech et al. 2003).

Adoptive transfer studies have demonstrated that, similar to Tem and Tcm cells, Trm cells originate from MPs. Specifically, $\mathrm{KLRG}^{+}$effector phase $\mathrm{T}$ cells failed to produce Trm cells in the skin and intestines, while KLRG1 ${ }^{-}$precursors were shown to yield Trm cells in both skin, liver, and small intestine (Mackay et al. 2013; Sheridan et al. 2014; Herndler-Brandstetter et al. 2018). In addition, a recent study by Herndler-Brandstetter et al., in which a genetic reporter for $k$ lrg1 expression was used, demonstrated that the $\mathrm{KLRG}^{+}$precursors that lose expression of this molecule during the contraction phase (referred to as “exKLRG1 cells") are able to generate circulating memory T-cell subsets and also significantly contribute to the Trm cell pool in the liver and small intestine after L. monocytogenes infection (Herndler-Brandstetter et al. 2018). Thus, circulating memory $\mathrm{T}$ cells and Trm cells both arise from precursors that either never acquired KLRG1 expression or that lost such expression prior to memory formation.

Work by Masopust et al. has demonstrated that Trm cells arise from early effectors that have seeded the tissue before the peak of response. Specifically, transient expression of gut-homing molecules was shown to peak around day 4.5 after infection, and day 7 effector phase $\mathrm{T}$ cells from the spleen were not able to form gut Trm cells anymore, while still being able to develop into circulating memory T cells (Masopust et al. 2010). Consistent with the possibility that there may be heterogeneity in $\mathrm{KLRG}^{-}$effector phase $\mathrm{T}$ cells with respect to the capacity to form tissue-resident memory, a recent report showed that day 7 effector phase $\mathrm{T}$ cells present in nonlymphoid tissues are transcriptionally and epigenetically distinct from MPs in the spleen (Milner et al. 2017). In addition, MPs are transcriptionally more diverse than TEs (Arsenio et al. 2014), providing some evidence for the notion that multiple MP lineages may exist. Whereas jointly these data suggest the possible existence of a Trm cell precursor, direct evidence (e.g., in the form of single-cell lineage-tracing experiments) is thus far lacking.

\section{FORMATION OF TISSUE-RESIDENT MEMORY CD8 ${ }^{+}$T CELLS: LOCAL FACTORS THAT PROMOTE Trm CELL DIFFERENTIATION INSIDE THE TISSUE}

Following the generation of effector phase $\mathrm{T}$ cells, a number of tissue-derived signals influ- 

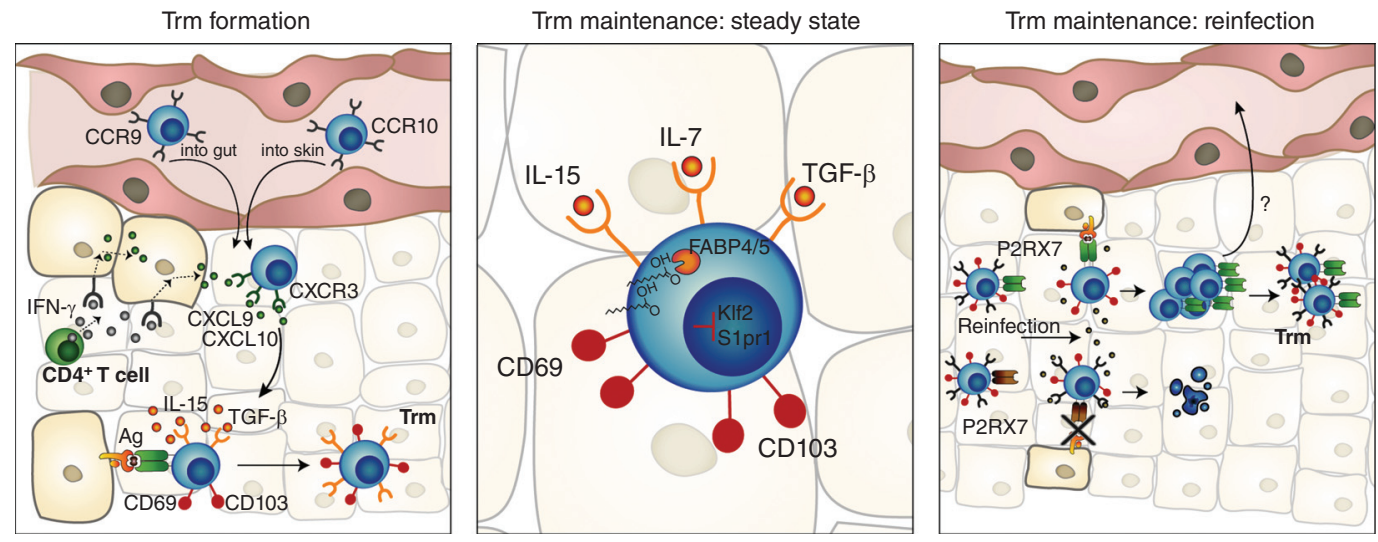

Figure 2. Establishment and maintenance of Trm cells in peripheral tissues. (Left panel) Effector phase T cells expressing tissue-specific homing molecules (e.g., CCR9 and CCR10) will enter the inflamed tissue. CD8 ${ }^{+} \mathrm{T}$ cells expressing the chemokine receptor CXCR3 selectively penetrate the tissue through sensing of the tissue-derived ligands CXCL9 and/or CXCL10. Activated CD4 ${ }^{+} \mathrm{T}$ cells can increase production of these ligands through local interferon $\gamma$ (IFN- $\gamma$ ) secretion. The subsequent exposure to antigen, interleukin (IL)-15, and transforming growth factor $\beta$ (TGF- $\beta$ ) during inflammation facilitate retention and survival of the infiltrated T cells, ultimately leading to the formation of $\mathrm{CD} 69^{+} \mathrm{CD}_{103}{ }^{+}$Trm cells. (Middle panel) In the absence of infection, $\mathrm{CD} 69^{+} \mathrm{CD} 103^{+}$ Trm cells possess the ability to persist within peripheral tissues, relying on local factors that facilitate their retention and maintenance. First, Trm cells require IL-15 and IL-7 for low homeostatic proliferation and survival, but also active TGF- $\beta$, which facilitates adhesion to E-cadherin-positive tissues through the induction of CD103 expression. Second, to allow sustained survival, Trm cells have been reported to require the uptake and metabolism of exogenous free fatty acids, for which the expression of FABP4 and FABP5 is essential. Together, these and other signals instruct a tissue-residency transcriptional profile that prevents the cells from exiting the tissue (i.e., with low KLF2 and S1PR1 expression) and facilitates long-term persistence. (Right panel) Local reinfection, which coincides with tissue damage, leads to the release of extracellular nucleotides. These factors induce cell death via activation of the damage-/danger-associated molecular pattern receptor P2RX7 expressed on Trm cells. However, upon TCR triggering, Trm cells down-regulate P2RX7, thereby promoting selective survival of pathogen-specific T cells. Trm cells that are activated by cognate antigen can also proliferate locally and, after pathogen clearance, give rise to a secondary pool of memory $\mathrm{T}$ cells. In addition, upon reinfection, antigen-specific Trm cells may exit the peripheral tissue and migrate to the draining lymph nodes (LNs).

ence their capacity to enter the tissue and subsequently differentiate into Trm cells. These factors can be grouped into a number of classes such as antigen, chemokines, cytokines, and metabolites. Here, we will discuss the key factors that promote the entry of effector phase $\mathrm{T}$ cells into the tissue, their differentiation into Trm cells, and their local long-term maintenance (i.e., the balance between proliferation and cell death) within tissues (see also Fig. 2).

\section{Factors that Promote Tissue Entry}

One of the key chemokine receptor-ligand pairs that facilitates localization of effector phase $\mathrm{T}$ cells into tissues is CXCR3 and its ligands
CXCL9 and CXCL10. Adoptive transfer experiments using CXCR3-deficient effector phase $\mathrm{T}$ cells demonstrated impaired Trm cell formation in the skin by such cells while formation of circulatory memory $\mathrm{T}$ cells was increased (Mackay et al. 2013). In line with these data, CXCR3 expression is higher on $\mathrm{KLRG1}^{-}$effector phase $\mathrm{T}$ cells that have been shown to preferentially yield Trm cells, as compared to KLRG1 ${ }^{+}$ effector phase T cells (Mackay et al. 2013). In addition, the KLRG1 ${ }^{-}$effector phase T compartment shows an increased capacity to migrate in response to CXCL10 in vitro, which is produced together with CXCL9 at inflamed tissue sites, such as in herpes simplex virus-1-infected skin (Mackay et al. 2013). Notably, topical applica- 
F.E. Dijkgraaf et al.

tion of CXCL9 and CXCL10 is sufficient to "pull" effector phase T cells to the vaginal mucosa in the absence of infection (Shin and Iwasaki 2012). In the vaginal mucosa and lung tissue, IFN- $\gamma$ production by activated $\mathrm{CD}^{+}{ }^{+} \mathrm{T}$ cells present at the inflamed site promotes tissue entry of Trm cells, presumably via local induction of CXCL9 and CXCL10 (Nakanishi et al. 2009; Laidlaw et al. 2014). Interestingly, these findings align well with data from a human study in which menstrual blood of healthy females or human immunodeficiency virus (HIV)-infected females that bear low $\mathrm{CD} 4^{+} \mathrm{T}$-cell counts was sampled, showing that $\mathrm{CD}^{+}{ }^{+} \mathrm{T}$-cell-derived IFN- $\gamma$ levels were correlated with $\mathrm{CD}_{103^{+}}$Trm cell numbers in the vaginal mucosa (Moylan et al. 2016).

\section{Factors that Promote Tissue Retention}

Upon entry into the tissue, effector phase T cells can encounter several factors that promote tissue retention, one of which is the local presence of antigen. Local antigen abundance has been shown to promote Trm cell numbers in all tissues examined (Khan et al. 2016; Muschaweckh et al. 2016; Davies et al. 2017). However, only the formation of $\mathrm{CD}_{103}{ }^{+}$Trm cells in the brain (Wakim et al. 2010) and both $\mathrm{CD}_{103}{ }^{+}$and $\mathrm{CD} 9^{+}$Trm cells in the lung (McMaster et al. 2018) was shown to fully depend on in situ TCR triggering. In addition, antigenic signals were shown to reduce the mean velocities of effector phase T cells in the skin (Macleod et al. 2014), thereby potentially prolonging their exposure to additional local factors that may promote Trm cell fate. As a third mechanism to explain the link between in situ antigen encounter and Trm cell formation, recognition of antigen at the tissue site may induce local proliferation (Kang et al. 2011).

In addition to antigen, tissue-derived cytokines play a crucial role in promoting Trm cell retention. One of the major drivers of $\mathrm{CD} 103$ expression, and to a lesser extent CD69, is TGF$\beta$ (El-Asady et al. 2005; Zhang and Bevan 2013). The different TGF- $\beta$ isoforms are ubiquitously expressed in several tissues including the skin (Kane et al. 1990) and intestines (Sheridan et al. 2014), and formation of $\mathrm{CD}_{103}{ }^{+}$Trm cells at these sites was shown to be dependent on this cytokine (Mackay et al. 2013; Zhang and Bevan 2013). TGF- $\beta$ signaling regulates T-bet and Eomes levels (see Box 1), thereby rendering cells responsive to local retention and survival signals (Mackay et al. 2013, 2015). In contrast, the formation of CD103- Trm cells in the intestines after bacterial infection is independent of TGF- $\beta$. Unlike CD103 ${ }^{+}$Trm cells, CD103- Trm cells in the lamina propria shown an uneven tissue distribution, with an apparent colocalization with $\mathrm{CD} 4^{+}$ $\mathrm{T}$ cells and $\mathrm{CX} 3 \mathrm{CR} 1^{+}$DCs and macrophages (Bergsbaken and Bevan 2015). Of note, production of proinflammatory cytokines (i.e., IFN- $\beta$ and IL-12) by macrophages within these niches was shown to counteract TGF- $\beta$-induced CD103 expression on effector phase $\mathrm{T}$ cells, thereby explaining the phenotype of these cells (Bergsbaken and Bevan 2015; Bergsbaken et al. 2017). At present, the niche-derived signals that are required for the local retention of this Trm cell subset have not been established. In vitro work has shown that several other proinflammatory cytokines may promote retention of $\mathrm{CD}^{+} \mathrm{T}$ cells (i.e., type I IFN, TNF- $\alpha$, and IL-33), by decreasing the expression of KLF2 and its target S1PR1 and increasing expression of CD69 on effector phase T cells (Casey et al. 2012; Skon et al. 2013), but the in vivo situations in which these pathways play a role have to our knowledge not been elucidated. Finally, next to antigen and cytokines, metabolites may also play a role in tissue retention. Specifically, hypoxia was shown to induce CD69 expression on activated murine and human T cells in vivo. Because the CD69 locus is a direct target of hypoxia-inducible factor $1 \alpha$ (Labiano et al. 2017), it is plausible that T-cell retention is promoted in hypoxic environments such as the skin.

\section{Factors that Promote Trm Cell Maintenance}

In the absence of infection, Trm cells in mice and humans show a limited degree of proliferation as measured by BrdU incorporation and Ki67 staining (Gebhardt et al. 2009; Kumar et al. 2017; Morris et al. 2019). Furthermore, in most tissues, the maintenance of Trm cell pools does not rely on influx from circulating memory 
$\mathrm{T}$ cells, as shown by antibody-mediated depletion of the circulating memory T-cell pool and adoptive transfer experiments (Masopust et al. 2010; Schenkel et al. 2013). As an exception, Trm cells generated upon influenza A infection in murine lung tissue fail to persist long term due to apoptosis and require replenishment from the circulation ( $\mathrm{Wu}$ et al. 2014; Slütter et al. 2017).

As Trm cell numbers remain stable in murine and human tissues up to several years (Gebhardt et al. 2009; Clark 2015) in spite of this limited proliferation and limited steady-state tissue entry, Trm cells can be considered long-lived cells in most tissues. Although Trm cells show phenotypic similarities with recently activated $\mathrm{T}$ cells and chronically stimulated $\mathrm{T}$ cells (i.e., CD69 and PD-1 expression) (Wakim et al. 2012; Mackay et al. 2013; Kumar et al. 2017), their persistence appears to be independent from antigenic stimulation in several tissues, including the lung (Mackay et al. 2012; Slütter et al. 2017). Whereas continued antigen encounter appears not required, homeostatic cytokines do play a crucial role in maintaining Trm cell populations. IL-15 has previously been shown to promote the proliferation and survival of Tem and Tcm cells (Schluns and Lefrançois 2003), and was subsequently shown to be required for the maintenance of virus-specific Trm cells in the skin (Mackay et al. 2013), salivary glands, and kidney (Schenkel et al. 2016). In murine epidermis, Trm cells localize close to hair follicles that constitutively produce IL-7 and IL-15. Accordingly, both cytokines are required for the maintenance of Trm cells in these epithelial niches (Adachi et al. 2015). IL-15 is not required in all tissues, as Trm cells in the vaginal mucosa, pancreas, and small intestine can develop normally in mice that lack this cytokine (Schenkel et al. 2016). Next to these cytokines, it has been proposed that activation of the integrin signaling pathway of CD103 and CD49a, which can be induced by TGF- $\beta$ (El-Asady et al. 2005; Zhang and Bevan 2013), provides survival signals to epithelial Trm cells (Ray et al. 2004; Wakim et al. 2010). The chemokine receptor CXCR6 has also been implied in Trm cell survival, as intradermally injected effector phase $\mathrm{T}$ cells de- ficient in CXCR6 showed impaired skin Trm cell formation, whereas memory T-cell formation in spleen was unaffected (Zaid et al. 2017).

In contrast to circulating memory $T$ cells, the survival of $\mathrm{CD}^{+}$Trm cells in skin relies on the consumption of exogenous free fatty acids (FFAs). This metabolic pathway is dependent on expression of intracellular fatty-acid-binding protein 4 (FABP4) and FABP5, and appears conserved between mice and humans (Pan et al. 2017). Given that FABP4 and 5, but also other FABP family members, are expressed in a tissue-specific manner by multiple cell types (e.g., macrophages, enterocytes) (Storch and Thumser 2010), Trm cell maintenance likely requires a specific metabolic state at other tissue sites as well. Finally, extracellular nucleotides (i.e., $\mathrm{ATP}^{+}, \mathrm{NAD}^{+}$) released upon tissue damage and infection, have been shown to regulate Trm cell maintenance in the liver and intestines. Specifically, activation of the damage-/dangerassociated molecular pattern receptor P2RX7 by extracellular nucleotides was shown to promote cell death in Trm cells. As TCR triggering in Trm cells leads to decreased expression of P2RX7, this process may be viewed as a mechanism to bias the local T-cell repertoire, by allowing the selective survival of antigen-specific Trm cells relative to bystander Trm cells (Stark et al. 2018).

\section{THERAPEUTIC STRATEGIES TO MANIPULATE Trm CELL BIOLOGY}

As shown above, the formation of Trm cell pools is indispensible for protection against recurrent local pathogens. For this reason, induction of these populations at nonlymphoid tissues should be a primary objective in T-cell-directed therapeutic or prophylactic vaccines. One strategy that has already proven successful in generating enhanced Trm cells is the "prime and pull" methodology (Shin and Iwasaki 2012). In this approach, conventional vaccination with an attenuated virus takes place to elicit a systemic T-cell response ("prime"), followed by topical application of chemoattractants to recruit effector phase T cells to the tissue ("pull"). Application of this strategy has been shown to generate 
F.E. Dijkgraaf et al.

protective Trm cells against herpes simplex virus-2 in the vaginal mucosa of both mice and guinea pigs (Shin and Iwasaki 2012; Bernstein et al. 2019). Given the more recent data indicating that, next to tissue-derived factors, early signals that $\mathrm{CD}^{+} \mathrm{T}$ cells receive prior to tissue entry also contribute to Trm cell formation, additional avenues may be considered. For example, a temporary preconditioning regimen in which active TGF- $\beta$ is delivered to naive $C D 8^{+}$ $\mathrm{T}$ cells in SLOs before vaccination may potentially increase formation of epithelial Trm cells (Mani et al. 2019). In addition, the targeting of cross-presenting DCs during priming, for instance by coupling antigens to monoclonal antibodies against CD103 or DNGR1 (Wakim et al. 2015; Iborra et al. 2016), could enhance formation of epithelial and mucosal Trm cells. Notably, the suggested application of rapamycin to enhance $\mathrm{CD}^{+}$T-cell responses during vaccination ( $\mathrm{Li}$ et al. 2012) may be contraindicated in strategies where the induction of local T-cell immunity is the primary objective.

Whereas Trm cells are necessary for protection against local reinfections, their presence is undesirable in autoimmune diseases, such as vitiligo and psoriasis, where these cells play a pathogenic role (Cheuk et al. 2017). As a preformed pathogenic Trm cell compartment is already present in these diseases, approaches that prevent the formation of novel Trm cells may be of modest value as monotherapies. However, strategies aimed at reducing the survival or retention of established Trm cell pools could potentially be attractive. Low-dose radiation therapy has been shown to eradicate malignant $\mathrm{T}$ cells in the skin and improve survival of patients with early-stage mycosis fungoides (i.e., lymphoma of T cells with a Trm cell phenotype) (O’Malley et al. 2020), but more defined strategies to target the Trm cell compartment would clearly be preferable. Conceivably, Trm cell pools may be targeted by administration of bispecific single-domain antibody drug conjugates (e.g., targeting CD69 and CD103) (Bannas et al. 2017), which are expected to penetrate into dense tissues such as the skin (Dijkgraaf et al. 2019). Alternatively, disruption of the signal transduction pathways that control Trm cell re- tention or maintenance, such as the IL-15 receptor signaling pathway, could be attractive, especially if local inhibition can be achieved.

\section{CONCLUDING REMARKS}

Data that has emerged over the past years makes it evident that Trm cell formation is regulated at several stages of the T-cell response. At the naive $\mathrm{T}$-cell stage, and also during $\mathrm{T}$-cell priming, the encounter of specialized DCs that provide specific signals plays a central role in the imprinting of the capacity to yield tissue-resident progeny. At the tissue site, the presence of local factors determines whether effector phase $\mathrm{T}$ cells with heightened sensitivity to such factors are retained locally and form a stable Trm cell compartment. Factors that regulate these processes include antigen, costimulatory molecules, cytokines, chemokines, and metabolites. Importantly, the presence of these factors may differ between individuals (Stelekati et al. 2014; Klein and Flanagan 2016; Zens et al. 2017), between pathogens and tissue types (Szabo et al. 2019), and even locally within tissue sites (Bergsbaken and Bevan 2015). Further insight into the key signals that create and maintain Trm cell populations in diverse tissues and under different (patho-)physiological conditions, will help us to steer Trm cell immunity. Early efforts already indicate that it is feasible to therapeutically target Trm cells, and a further effort to design strategies that may be used to either boost or deplete tissue-specific resident $\mathrm{CD}^{+}$memory $\mathrm{T}$ cells is clearly warranted.

\section{REFERENCES}

Adachi T, Kobayashi T, Sugihara E, Yamada T, Ikuta K, Pittaluga S, Saya H, Amagai M, Nagao K. 2015. Hair follicle-derived IL-7 and IL-15 mediate skin-resident memory $\mathrm{T}$ cell homeostasis and lymphoma. Nat Med 21: 1272-1279. doi:10.1038/nm.3962

Amsen D, van Gisbergen K, Hombrink P, van Lier RAW. 2018. Tissue-resident memory $\mathrm{T}$ cells at the center of immunity to solid tumors. Nat Immunol 19: 538-546. doi:10.1038/s41590-018-0114-2

Ariotti S, Beltman JB, Chodaczek G, Hoekstra ME, van Beek AE, Gomez-Eerland R, Ritsma L, van Rheenen J, Marée AFM, Zal T, et al. 2012. Tissue-resident memory CD8 $\mathrm{T}$ cells continuously patrol skin epithelia to quickly rec- 
ognize local antigen. Proc Natl Acad Sci 109: 1973919744. doi:10.1073/pnas.1208927109

Ariotti S, Hogenbirk MA, Dijkgraaf FE, Visser LL, Hoekstra ME, Song JY, Jacobs H, Haanen JB, Schumacher TN. 2014. T cell memory. Skin-resident memory $\mathrm{CD}^{+} \mathrm{T}$ cells trigger a state of tissue-wide pathogen alert. Science 346: 101-105. doi:10.1126/science. 1254803

Arsenio J, Kakaradov B, Metz PJ, Kim SH, Yeo GW, Chang JT. 2014. Early specification of $\mathrm{CD} 8^{+} \mathrm{T}$ lymphocyte fates during adaptive immunity revealed by single-cell geneexpression analyses. Nat Immunol 15: 365-372. doi:10 $.1038 /$ ni. 2842

Bai A, Hu H, Yeung M, Chen J. 2007. Krüppel-like factor 2 controls $\mathrm{T}$ cell trafficking by activating $\mathrm{L}$-selectin (CD62L) and sphingosine-1-phosphate receptor 1 transcription. J Immunol 178: 7632-7639. doi:10.4049/jimmu nol.178.12.7632

Bankovich AJ, Shiow LR, Cyster JG. 2010. CD69 suppresses sphingosine 1-phosophate receptor-1 $\left(\mathrm{S}_{1} \mathrm{P}_{1}\right)$ function through interaction with membrane helix 4. J Biol Chem 285: 22328-22337. doi:10.1074/jbc.M110.123299

Bannas P, Hambach J, Koch-Nolte F. 2017. Nanobodies and nanobody-based human heavy chain antibodies as antitumor therapeutics. Front Immunol 8: 1603. doi:10.3389/ fimmu.2017.01603

Behr FM, Chuwonpad A, Stark R, van Gisbergen K. 2018. Armed and ready: transcriptional regulation of tissueresident memory CD8 T cells. Front Immunol 9: 1770. doi:10.3389/fimmu.2018.01770

Behr FM, Kragten NAM, Wesselink TH, Nota B, van Lier RAW, Amsen D, Stark R, Hombrink P, van Gisbergen KPJM. 2019. Blimp-1 rather than Hobit drives the formation of tissue-resident memory $\mathrm{CD}^{+} \mathrm{T}$ cells in the lungs. Front Immunol 10: 400. doi:10.3389/fimmu.2019.00400

Bergsbaken T, Bevan MJ. 2015. Proinflammatory microenvironments within the intestine regulate the differentiation of tissue-resident $\mathrm{CD}^{+} \mathrm{T}$ cells responding to infection. Nat Immunol 16: 406-414. doi:10.1038/ni.3108

Bergsbaken T, Bevan MJ, Fink PJ. 2017. Local inflammatory cues regulate differentiation and persistence of $\mathrm{CD} 8^{+}$tissue-resident memory T cells. Cell Rep 19: 114-124. doi:10 $.1016 /$ j.celrep.2017.03.031

Bernstein DI, Cardin RD, Bravo FJ, Awasthi S, Lu P, Pullum DA, Dixon DA, Iwasaki A, Friedman HM. 2019. Successful application of prime and pull strategy for a therapeutic HSV vaccine. NPJ Vaccines 4: 33. doi:10.1038/s41541019-0129-1

Beura LK, Wijeyesinghe S, Thompson EA, Macchietto MG, Rosato PC, Pierson MJ, Schenkel JM, Mitchell JS, Vezys V, Fife BT, et al. 2018a. T cells in nonlymphoid tissues give rise to lymph-node-resident memory T cells. Immunity 48: 327-338.e5. doi:10.1016/j.immuni.2018.01.015

Beura LK, Mitchell JS, Thompson EA, Schenkel JM, Mohammed J, Wijeyesinghe S, Fonseca R, Burbach BJ, Hickman HD, Vezys V, et al. 2018b. Intravital mucosal imaging of $\mathrm{CD}^{+}$resident memory $\mathrm{T}$ cells shows tissueautonomous recall responses that amplify secondary memory. Nat Immunol 19: 173-182. doi:10.1038/ s41590-017-0029-3

Boddupalli CS, Nair S, Gray SM, Nowyhed HN, Verma R, Gibson JA, Abraham C, Narayan D, Vasquez J, Hedrick CC, et al. 2016. ABC transporters and NR4A1 identify a quiescent subset of tissue-resident memory T cells. J Clin Invest 126: 3905-3916. doi:10.1172/JCI85329

Böttcher JP, Beyer M, Meissner F, Abdullah Z, Sander J, Höchst B, Eickhoff S, Rieckmann JC, Russo C, Bauer T, et al. 2015. Functional classification of memory $\mathrm{CD} 8^{+}$ T cells by CX3CR1 expression. Nat Commun 6: 8306 . doi: $10.1038 /$ ncomms 9306

Buchholz VR, Flossdorf M, Hensel I, Kretschmer L, Weissbrich B, Gräf P, Verschoor A, Schiemann M, Höfer T, Busch DH. 2013. Disparate individual fates compose robust $\mathrm{CD}^{+} \mathrm{T}$ cell immunity. Science 340: 630-635. doi:10 $.1126 /$ science. 1235454

Casey KA, Fraser KA, Schenkel JM, Moran A, Abt MC, Beura LK, Lucas PJ, Artis D, Wherry EJ, Hogquist K, et al. 2012. Antigen-independent differentiation and maintenance of effector-like resident memory $\mathrm{T}$ cells in tissues. J Immunol 188: 4866-4875. doi:10.4049/jimmunol .1200402

Cheuk S, Schlums H, Sérézal IG, Martini E, Chiang SC, Marquardt N, Gibbs A, Detlofsson E, Introini A, Forke $\mathrm{M}$, et al. 2017. CD49a expression defines tissue-resident $\mathrm{CD}^{+} \mathrm{T}$ cells poised for cytotoxic function in human skin. Immunity 46: 287-300. doi:10.1016/j.immuni.2017.01 .009

Clark RA. 2015. Resident memory T cells in human health and disease. Sci Transl Med 7: 269rv1. doi:10.1126/sci translmed.3010641

Clark RA, Watanabe R, Teague JE, Schlapbach C, Tawa MC, Adams N, Dorosario AA, Chaney KS, Cutler CS, Leboeuf NR, et al. 2012. Skin effector memory T cells do not recirculate and provide immune protection in alemtuzumab-treated CTCL patients. Sci Transl Med 4: 117ra7. doi:10.1126/scitranslmed.3003008

Davies B, Prier JE, Jones CM, Gebhardt T, Carbone FR, Mackay LK. 2017. Cutting edge: tissue-resident memory $\mathrm{T}$ cells generated by multiple immunizations or localized deposition provide enhanced immunity. J Immunol 198: 2233-2237. doi:10.4049/jimmunol.1601367

Dijkgraaf FE, Matos TR, Hoogenboezem M, Toebes M, Vredevoogd DW, Mertz M, van den Broek B, Song JY, Teunissen MBM, Luiten RM, et al. 2019. Tissue patrol by resident memory $\mathrm{CD}^{+} \mathrm{T}$ cells in human skin. Nat Immunol 20: 756-764. doi:10.1038/s41590-019-0404-3

Djenidi F, Adam J, Goubar A, Durgeau A, Meurice G, de Montpréville V, Validire P, Besse B, Mami-Chouaib F. 2015. $\mathrm{CD} 8^{+} \mathrm{CD} 103^{+}$tumor-infiltrating lymphocytes are tumor-specific tissue-resident memory $\mathrm{T}$ cells and a prognostic factor for survival in lung cancer patients. $J$ Immunol 194: 3475-3486. doi:10.4049/jimmunol.140 2711

Duhen T, Duhen R, Montler R, Moses J, Moudgil T, de Miranda NF, Goodall CP, Blair TC, Fox BA, McDermott JE, et al. 2018. Co-expression of CD39 and CD103 identifies tumor-reactive CD8 T cells in human solid tumors. Nat Commun 9: 2724. doi:10.1038/s41467-018-05072-0

Edwards J, Wilmott JS, Madore J, Nur Gide T, Quek C, Tasker A, Ferguson A, Chen J, Hewavisenti R, Hersey P, et al. 2018. $\mathrm{CD} 103^{+}$tumor-resident $\mathrm{CD} 8^{+} \mathrm{T}$ cells are associated with improved survival in immunotherapy-naive melanoma patients and expand significantly during antiPD-1 treatment. Clin Cancer Res 24: 3036-3045. doi:10 .1158/1078-0432.CCR-17-2257 
F.E. Dijkgraaf et al.

El-Asady R, Yuan R, Liu K, Wang D, Gress RE, Lucas PJ, Drachenberg CB, Hadley GA. 2005. TGF- $\beta$-dependent CD103 expression by $\mathrm{CD}^{+} \mathrm{T}$ cells promotes selective destruction of the host intestinal epithelium during graft-versus-host disease. J Exp Med 201: 1647-1657. doi:10.1084/jem.20041044

Enamorado M, Khouili SC, Iborra S, Sancho D. 2018. Genealogy, dendritic cell priming, and differentiation of tissueresident memory CD8 ${ }^{+} \mathrm{T}$ cells. Front Immunol 9: 1751 . doi:10.3389/fimmu.2018.01751

Fernandez-Ruiz D, Ng WY, Holz LE, Ma JZ, Zaid A, Wong YC, Lau LS, Mollard V, Cozijnsen A, Collins N, et al. 2016. Liver-resident memory $\mathrm{CD}^{+} \mathrm{T}$ cells form a front-line defense against malaria liver-stage infection. Immunity 45: 889-902. doi:10.1016/j.immuni.2016.08.011

Fiege JK, Stone IA, Fay EJ, Markman MW, Wijeyesinghe S, Macchietto MG, Shen S, Masopust D, Langlois RA. 2019. The impact of TCR signal strength on resident memory $\mathrm{T}$ cell formation during influenza virus infection. J Immunol 203: 936-945. doi:10.4049/jimmunol.1900093

Frost EL, Kersh AE, Evavold BD, Lukacher AE. 2015. Cutting edge: resident memory CD8 T cells express highaffinity TCRs. J Immunol 195: 3520-3524. doi:10.4049/ jimmunol.1501521

Gaide O, Emerson RO, Jiang X, Gulati N, Nizza S, Desmarais C, Robins H, Krueger JG, Clark RA, Kupper TS. 2015 Common clonal origin of central and resident memory $\mathrm{T}$ cells following skin immunization. Nat Med 21: 647-653. doi:10.1038/nm.3860

Ganesan AP, Clarke J, Wood O, Garrido-Martin EM, Chee SJ, Mellows T, Samaniego-Castruita D, Singh D, Seumois G, Alzetani A, et al. 2017. Tissue-resident memory features are linked to the magnitude of cytotoxic $T$ cell responses in human lung cancer. Nat Immunol 18: 940950. doi:10.1038/ni.3775

Gebhardt T, Wakim LM, Eidsmo L, Reading PC, Heath WR, Carbone FR. 2009. Memory T cells in nonlymphoid tissue that provide enhanced local immunity during infection with herpes simplex virus. Nat Immunol 10: 524-530. doi:10.1038/ni.1718

Gebhardt T, Palendira U, Tscharke DC, Bedoui S. 2018. Tissue-resident memory $\mathrm{T}$ cells in tissue homeostasis, persistent infection, and cancer surveillance. Immunol Rev 283: 54-76. doi:10.1111/imr.12650

Gerlach C, van Heijst JWJ, Swart E, Sie D, Armstrong N, Kerkhoven RM, Zehn D, Bevan MJ, Schepers K, Schumacher TNM. 2010. One naive T cell, multiple fates in $\mathrm{CD}^{+} \mathrm{T}$ cell differentiation. J Exp Med 207: 1235-1246. doi:10.1084/jem.20091175

Gerlach C, van Heijst JW, Schumacher TN. 2011. The descent of memory T cells. Ann NY Acad Sci 1217: 139-153. doi:10.1111/j.1749-6632.2010.05830.x

Gerlach C, Rohr JC, Perié L, van Rooij N, van Heijst JW, Velds A, Urbanus J, Naik SH, Jacobs H, Beltman JB, et al. 2013. Heterogeneous differentiation patterns of individual CD8 ${ }^{+}$T cells. Science 340: 635-639. doi:10.1126/sci ence. 1235487

Gerlach C, Moseman EA, Loughhead SM, Alvarez D, Zwijnenburg AJ, Waanders L, Garg R, de la Torre J, von Andrian UH. 2016. The chemokine receptor CX3CR1 defines three antigen-experienced CD8 T cell subsets with distinct roles in immune surveillance and homeosta- sis. Immunity 45: 1270-1284. doi:10.1016/j.immuni.2016 .10 .018

Gutiérrez-Vázquez C, Quintana FJ. 2018. Regulation of the immune response by the aryl hydrocarbon receptor. Immunity 48: 19-33. doi:10.1016/j.immuni.2017.12.012

Herndler-Brandstetter D, Ishigame H, Shinnakasu R, Plajer V, Stecher C, Zhao J, Lietzenmayer M, Kroehling L, Takumi A, Kometani K, et al. 2018. $\mathrm{KLRG}^{+}$effector $\mathrm{CD}^{+}$ $\mathrm{T}$ cells lose KLRG1, differentiate into all memory $\mathrm{T}$ cell lineages, and convey enhanced protective immunity. Immunity 48: 716-729.e8. doi:10.1016/j.immuni.2018.03 .015

Hofmann M, Pircher H. 2011. E-cadherin promotes accumulation of a unique memory CD8 T-cell population in murine salivary glands. Proc Natl Acad Sci 108: 1674116746. doi:10.1073/pnas.1107200108

Hombrink P, Helbig C, Backer RA, Piet B, Oja AE, Stark R, Brasser G, Jongejan A, Jonkers RE, Nota B, et al. 2016. Programs for the persistence, vigilance and control of human $\mathrm{CD}^{+}$lung-resident memory T cells. Nat Immunol 17: 1467-1478. doi:10.1038/ni.3589

Hu W, Sun R, Chen L, Zheng X, Jiang J. 2019. Prognostic significance of resident $\mathrm{CD}_{103}{ }^{+} \mathrm{CD}^{+} \mathrm{T}$ cells in human colorectal cancer tissues. Acta Histochem 121: 657-663. doi:10.1016/j.acthis.2019.05.009

Iborra S, Martínez-López M, Khouili SC, Enamorado M, Cueto FJ, Conde-Garrosa R, Del Fresno C, Sancho D. 2016. Optimal generation of tissue-resident but not circulating memory $\mathrm{T}$ cells during viral infection requires crosspriming by DNGR $-1^{+}$dendritic cells. Immunity 45: 847-860. doi:10.1016/j.immuni.2016.08.019

Iwata M, Hirakiyama A, Eshima Y, Kagechika H, Kato C, Song SY. 2004. Retinoic acid imprints gut-homing specificity on T cells. Immunity 21: 527-538. doi:10.1016/j .immuni.2004.08.011

Jiang X, Clark RA, Liu L, Wagers AJ, Fuhlbrigge RC, Kupper TS. 2012. Skin infection generates non-migratory memory CD8 ${ }^{+} \mathrm{T}_{\mathrm{RM}}$ cells providing global skin immunity. $\mathrm{Na}$ ture 483: 227-231. doi:10.1038/nature10851

Joshi NS, Cui W, Chandele A, Lee HK, Urso DR, Hagman J, Gapin L, Kaech SM. 2007. Inflammation directs memory precursor and short-lived effector $\mathrm{CD}^{+} \mathrm{T}$ cell fates via the graded expression of T-bet transcription factor. Immunity 27: 281-295. doi:10.1016/j.immuni.2007.07.010

Kadow S, Jux B, Zahner SP, Wingerath B, Chmill S, Clausen BE, Hengstler J, Esser C. 2011. Aryl hydrocarbon receptor is critical for homeostasis of invariant $\gamma \delta \mathrm{T}$ cells in the murine epidermis. J Immunol 187: 3104-3110. doi:10 .4049/jimmunol.1100912

Kaech SM, Cui W. 2012. Transcriptional control of effector and memory CD8 ${ }^{+} \mathrm{T}$ cell differentiation. Nat Rev Immunol 12: 749-761. doi:10.1038/nri3307

Kaech SM, Tan JT, Wherry EJ, Konieczny BT, Surh CD, Ahmed R. 2003. Selective expression of the interleukin 7 receptor identifies effector CD8 $\mathrm{T}$ cells that give rise to long-lived memory cells. Nat Immunol 4: 1191-1198. doi:10.1038/ni1009

Kane CJ, Knapp AM, Mansbridge JN, Hanawalt PC. 1990. Transforming growth factor- $\beta 1$ localization in normal and psoriatic epidermal keratinocytes in situ. J Cell Physiol 144: 144-150. doi:10.1002/jcp.1041440119 
Kang SS, Herz J, Kim JV, Nayak D, Stewart-Hutchinson P, Dustin ML, McGavern DB. 2011. Migration of cytotoxic lymphocytes in cell cycle permits local MHC I-dependent control of division at sites of viral infection. J Exp Med 208: 747-759. doi:10.1084/jem.20101295

Khan TN, Mooster JL, Kilgore AM, Osborn JF, Nolz JC. 2016. Local antigen in nonlymphoid tissue promotes resident memory $\mathrm{CD} 8^{+} \mathrm{T}$ cell formation during viral infection. J Exp Med 213: 951-966. doi:10.1084/jem.20151855

Klein SL, Flanagan KL. 2016. Sex differences in immune responses. Nat Rev Immunol 16: 626-638. doi:10.1038/ nri.2016.90

Komdeur FL, Prins TM, van de Wall S, Plat A, Wisman GBA, Hollema H, Daemen T, Church DN, de Bruyn M, Nijman HW. 2017. CD103 ${ }^{+}$tumor-infiltrating lymphocytes are tumor-reactive intraepithelial $\mathrm{CD}^{+} \mathrm{T}$ cells associated with prognostic benefit and therapy response in cervical cancer. Oncoimmunology 6: e1338230. doi:10 .1080/2162402X.2017.1338230

Kumar BV, Ma W, Miron M, Granot T, Guyer RS, Carpenter DJ, Senda T, Sun X, Ho SH, Lerner H, et al. 2017. Human tissue-resident memory $\mathrm{T}$ cells are defined by core transcriptional and functional signatures in lymphoid and mucosal sites. Cell Rep 20: 2921-2934. doi:10.1016/j .celrep.2017.08.078

Labiano S, Meléndez-Rodríguez F, Palazón A, Teijeira A, Garasa S, Etxeberria I, Aznar MA, Sánchez-Paulete AR, Azpilikueta A, Bolaños E, et al. 2017. CD69 is a direct HIF-1 $\alpha$ target gene in hypoxia as a mechanism enhancing expression on tumor-infiltrating T lymphocytes. Oncoimmunology 6: e1283468. doi:10.1080/2162402X.2017 .1283468

Laidlaw BJ, Zhang N, Marshall HD, Staron MM, Guan T, Hu Y, Cauley LS, Craft J, Kaech SM. 2014. CD4 ${ }^{+}$T cell help guides formation of $\mathrm{CD} 13^{+}$lung-resident memory $\mathrm{CD}^{+} \mathrm{T}$ cells during influenza viral infection. Immunity 41: 633-645. doi:10.1016/j.immuni.2014.09.007

Lal L, Li Y, Smith J, Sassano A, Uddin S, Parmar S, Tallman MS, Minucci S, Hay N, Platanias LC. 2005. Activation of the p70 S6 kinase by all-trans-retinoic acid in acute promyelocytic leukemia cells. Blood 105: 1669-1677. doi:10 .1182/blood-2004-06-2078

Li Y, Innocentin S, Withers DR, Roberts NA, Gallagher AR, Grigorieva EF, Wilhelm C, Veldhoen M. 2011. Exogenous stimuli maintain intraepithelial lymphocytes via aryl hydrocarbon receptor activation. Cell 147: 629-640. doi:10 .1016/j.cell.2011.09.025

Li Q, Rao R, Vazzana J, Goedegebuure P, Odunsi K, Gillanders W, Shrikant PA. 2012. Regulating mammalian target of rapamycin to tune vaccination-induced $\mathrm{CD} 8^{+}$ $\mathrm{T}$ cell responses for tumor immunity. J Immunol 188: 3080-3087. doi:10.4049/jimmunol.1103365

Li J, Olshansky M, Carbone FR, Ma JZ. 2016. Transcriptional analysis of T cells resident in human skin. PLOS ONE 11: e0148351. doi:10.1371/journal.pone.0148351

Li C, Zhu B, Son YM, Wang Z, Jiang L, Xiang M, Ye Z, Beckermann KE, Wu Y, Jenkins JW, et al. 2019a. The transcription factor Bhlhe 40 programs mitochondrial regulation of resident $\mathrm{CD} 8^{+} \mathrm{T}$ cell fitness and functionality. Immunity 51: 491-507.e7. doi:10.1016/j.immuni .2019 .08 .013
Li H, van der Leun AM, Yofe I, Lubling Y, Gelbard-Solodkin D, van Akkooi ACJ, van den Braber M, Rozeman EA, Haanen JBAG, Blank CU, et al. 2019b. Dysfunctional CD8 T cells form a proliferative, dynamically regulated compartment within human melanoma. Cell 176: 775789.e18. doi:10.1016/j.cell.2018.11.043

Mackay LK, Stock AT, Ma JZ, Jones CM, Kent SJ, Mueller SN, Heath WR, Carbone FR, Gebhardt T. 2012. Longlived epithelial immunity by tissue-resident memory $\mathrm{T}$ (TRM) cells in the absence of persisting local antigen presentation. Proc Natl Acad Sci 109: 7037-7042. doi:10 $.1073 /$ pnas. 1202288109

Mackay LK, Rahimpour A, Ma JZ, Collins N, Stock AT, Hafon ML, Vega-Ramos J, Lauzurica P, Mueller SN, Stefanovic T, et al. 2013. The developmental pathway for $\mathrm{CD}_{103}{ }^{+} \mathrm{CD}^{+}$tissue-resident memory $\mathrm{T}$ cells of skin. Nat Immunol 14: 1294-1301. doi:10.1038/ni.2744

Mackay LK, Wynne-Jones E, Freestone D, Pellicci DG, Mielke LA, Newman DM, Braun A, Masson F, Kallies A, Belz GT, et al. 2015. T-box transcription factors combine with the cytokines TGF- $\beta$ and IL- 15 to control tissue-resident memory $\mathrm{T}$ cell fate. Immunity 43: 11011111. doi:10.1016/j.immuni.2015.11.008

Mackay LK, Minnich M, Kragten NAM, Liao Y, Nota B, Seillet C, Zaid A, Man K, Preston S, Freestone D, et al. 2016. Hobit and Blimp1 instruct a universal transcriptional program of tissue residency in lymphocytes. Science 352: 459-463. doi:10.1126/science.aad2035

Macleod BL, Bedoui S, Hor JL, Mueller SN, Russell TA, Hollett NA, Heath WR, Tscharke DC, Brooks AG, Gebhardt. 2014. Distinct APC subtypes drive spatially segregated $\mathrm{CD}_{4}^{+}$and $\mathrm{CD} 8^{+} \mathrm{T}$-cell effector activity during skin infection with HSV-1. PLoS Pathog 10: e1004303. doi:10 .1371/journal.ppat.1004303

Mani V, Bromley SK, Äijö T, Mora-Buch R, Carrizosa E, Warner RD, Hamze M, Sen DR, Chasse AY, Lorant A, et al. 2019. Migratory DCs activate TGF- $\beta$ to precondition naive $\mathrm{CD} 8^{+} \mathrm{T}$ cells for tissue-resident memory fate. Science 366: eaav5728. doi:10.1126/science.aav5728

Maru S, Jin G, Schell TD, Lukacher AE. 2017. TCR stimulation strength is inversely associated with establishment of functional brain-resident memory CD8 T cells during persistent viral infection. PLoS Pathog 13: e1006318. doi:10.1371/journal.ppat.1006318

Masopust D, Schenkel JM. 2013. The integration of T cell migration, differentiation and function. Nat Rev Immunol 13: 309-320. doi:10.1038/nri3442

Masopust D, Choo D, Vezys V, Wherry EJ, Duraiswamy J, Akondy R, Wang J, Casey KA, Barber DL, Kawamura KS, et al. 2010. Dynamic T cell migration program provides resident memory within intestinal epithelium. J Exp Med 207: 553-564. doi:10.1084/jem.20090858

McMaster SR, Wein AN, Dunbar PR, Hayward SL, Cartwright EK, Denning TL, Kohlmeier JE. 2018. Pulmonary antigen encounter regulates the establishment of tissueresident CD8 memory $\mathrm{T}$ cells in the lung airways and parenchyma. Mucosal Immunol 11: 1071-1078. doi:10 .1038/s41385-018-0003-x

McNamara HA, Cai Y, Wagle MV, Sontani Y, Roots CM, Miosge LA, O'COnnor JH, Sutton HJ, Ganusov VV, Heath WR, et al. 2017. Up-regulation of LFA-1 allows liver-resident memory $\mathrm{T}$ cells to patrol and remain in 
F.E. Dijkgraaf et al.

the hepatic sinusoids. Sci Immunol 2: eaaj1996. doi:10 .1126/sciimmunol.aaj1996

Milner JJ, Toma C, Yu B, Zhang K, Omilusik K, Phan AT, Wang D, Getzler AJ, Nguyen T, Crotty S, et al. 2017. Runx3 programs $\mathrm{CD}^{+} \mathrm{T}$ cell residency in non-lymphoid tissues and tumours. Nature 552: 253-257. doi:10.1038/ nature 24993

Morris SE, Farber DL, Yates AJ. 2019. Tissue-resident memory $\mathrm{T}$ cells in mice and humans: towards a quantitative ecology. J Immunol 203: 2561-2569. doi:10.4049/jimmu nol.1900767

Moylan DC, Goepfert PA, Kempf MC, Saag MS, Richter HE, Mestecky J, Sabbaj S. 2016. Diminished CD103 ( $\alpha E \beta 7)$ expression on resident $\mathrm{T}$ cells from the female genital tract of HIV-positive women. Pathog Immun 1: 371-387. doi:10.20411/pai.vli2.166

Muschaweckh A, Buchholz VR, Fellenzer A, Hessel C, König PA, Tao S, Tao R, Heikenwälder M, Busch DH, Korn T, et al. 2016. Antigen-dependent competition shapes the local repertoire of tissue-resident memory CD8 ${ }^{+}$T cells. J Exp Med 213: 3075-3086. doi:10.1084/ jem.20160888

Nakanishi Y, Lu B, Gerard C, Iwasaki A. 2009. CD8 ${ }^{+}$ T lymphocyte mobilization to virus-infected tissue requires $\mathrm{CD}^{+}{ }^{+}$T-cell help. Nature 462: 510-513. doi:10 $.1038 /$ nature 08511

O’Malley JT, de Masson A, Lowry EL, Giobbie-Hurder A, LeBoeuf NR, Larocca C, Gehad A, Seger E, Teague JE, Fisher DC, et al. 2020. Radiotherapy eradicates malignant $\mathrm{T}$ cells and is associated with improved survival in earlystage mycosis fungoides. Clin Cancer Res 26: 408-418. doi:10.1158/1078-0432.CCR-18-4147

Pallett LJ, Davies J, Colbeck EJ, Robertson F, Hansi N, Easom NJW, Burton AR, Stegmann KA, Schurich A, Swadling L et al. 2017. IL-2 ${ }^{\text {high }}$ tissue-resident $\mathrm{T}$ cells in the human liver: sentinels for hepatotropic infection. J Exp Med 214: 1567-1580. doi:10.1084/jem.20162115

Pan Y, Tian T, Park CO, Lofftus SY, Mei S, Liu X, Luo C, O'Malley JT, Gehad A, Teague JE, et al. 2017. Survival of tissue-resident memory $\mathrm{T}$ cells requires exogenous lipid uptake and metabolism. Nature 543: 252-256. doi:10 $.1038 /$ nature21379

Park SL, Zaid A, Hor JL, Christo SN, Prier JE, Davies B, Alexandre YO, Gregory JL, Russell TA, Gebhardt T, et al. 2018. Local proliferation maintains a stable pool of tissue-resident memory $\mathrm{T}$ cells after antiviral recall responses. Nat Immunol 19: 183-191. doi:10.1038/ s41590-017-0027-5

Park SL, Buzzai A, Rautela J, Hor JL, Hochheiser K, Effern M, McBain N, Wagner T, Edwards J, McConville R, et al. 2019a. Tissue-resident memory $\mathrm{CD}^{+} \mathrm{T}$ cells promote melanoma-immune equilibrium in skin. Nature 565: 366-371. doi:10.1038/s41586-018-0812-9

Park SL, Gebhardt T, Mackay LK. 2019b. Tissue-resident memory $\mathrm{T}$ cells in cancer immunosurveillance. Trends Immunol 40: 735-747. doi:10.1016/j.it.2019.06.002

Pizzolla A, Nguyen TH, Sant S, Jaffar J, Loudovaris T, Mannering SI, Thomas PG, Westall GP, Kedzierska K, Wakim LM. 2018. Influenza-specific lung-resident memory $\mathrm{T}$ cells are proliferative and polyfunctional and maintain diverse TCR profiles. J Clin Invest 128: 721-733. doi:10 $.1172 /$ JCI96957
Ray SJ, Franki SN, Pierce RH, Dimitrova S, Koteliansky V, Sprague AG, Doherty PC, de Fougerolles AR, Topham DJ. 2004. The collagen binding $\alpha 1 \beta 1$ integrin VLA-1 regulates CD8 T cell-mediated immune protection against heterologous influenza infection. Immunity 20: 167-179. doi:10.1016/S1074-7613(04)00021-4

Sanecka A, Yoshida N, Motunrayo Kolawole E, Patel H, Evavold BD, Frickel EM. 2018. T cell receptor-major histocompatibility complex interaction strength defines trafficking and $\mathrm{CD} 103^{+}$memory status of CD8 T cells in the brain. Front Immunol 9: 1290. doi:10.3389/fimmu.2018 .01290

Savas P, Virassamy B, Ye C, Salim A, Mintoff CP, Caramia F, Salgado R, Byrne DJ, Teo ZL, Dushyanthen S, et al. 2018. Single-cell profiling of breast cancer T cells reveals a tissue-resident memory subset associated with improved prognosis. Nat Med 24: 986-993. doi:10.1038/s41591018-0078-7

Schenkel JM, Fraser KA, Vezys V, Masopust D. 2013. Sensing and alarm function of resident memory $\mathrm{CD}^{+}$T cells. Nat Immunol 14: 509-513. doi:10.1038/ni .2568

Schenkel JM, Fraser KA, Beura LK, Pauken KE, Vezys V, Masopust D. 2014. T cell memory. Resident memory CD8 $\mathrm{T}$ cells trigger protective innate and adaptive immune responses. Science 346: 98-101. doi:10.1126/sci ence. 1254536

Schenkel JM, Fraser KA, Casey KA, Beura LK, Pauken KE, Vezys V, Masopust D. 2016. IL-15-independent maintenance of tissue-resident and boosted effector memory CD8 T cells. J Immunol 196: 3920-3926. doi:10.4049/ jimmunol.1502337

Schiffer JT, Abu-Raddad L, Mark KE, Zhu J, Selke S, Koelle DM, Wald A, Corey L. 2010. Mucosal host immune response predicts the severity and duration of herpes simplex virus-2 genital tract shedding episodes. Proc Natl Acad Sci 107: 18973-18978. doi:10.1073/pnas .1006614107

Schiffer JT, Swan DA, Corey L, Wald A. 2013. Rapid viral expansion and short drug half-life explain the incomplete effectiveness of current herpes simplex virus 2-directed antiviral agents. Antimicrob Agents Chemother 57: 5820 5829. doi:10.1128/AAC.01114-13

Schiffer JT, Swan DA, Prlic M, Lund JM. 2018. Herpes simplex virus-2 dynamics as a probe to measure the extremely rapid and spatially localized tissue-resident T-cell response. Immunol Rev 285: 113-133. doi:10.1111/imr .12672

Schluns KS, Lefrançois L. 2003. Cytokine control of memory T-cell development and survival. Nat Rev Immunol 3 269-279. doi:10.1038/nri1052

Sheridan BS, Pham QM, Lee YT, Cauley LS, Puddington L, Leo Lefrançois L. 2014. Oral infection drives a distinct population of intestinal resident memory $\mathrm{CD}^{+} \mathrm{T}$ cells with enhanced protective function. Immunity 40: $747-$ 757. doi:10.1016/j.immuni.2014.03.007

Shin H, Iwasaki A. 2012. A vaccine strategy that protects against genital herpes by establishing local memory T cells. Nature 491: 463-467. doi:10.1038/nature 11522

Sigmundsdottir H, Butcher EC. 2008. Environmental cues, dendritic cells and the programming of tissue-selective 
lymphocyte trafficking. Nat Immunol 9: 981-987. doi:10 $.1038 /$ ni.f.208

Sigmundsdottir H, Pan J, Debes GF, Alt C, Habtezion A, Soler D, Butcher EC. 2007. DCs metabolize sunlight-induced vitamin D3 to "program" T cell attraction to the epidermal chemokine CCL27. Nat Immunol 8: 285-293. doi:10.1038/ni1433

Skon CN, Lee JY, Anderson KG, Masopust D, Hogquist KA, Jameson SC. 2013. Transcriptional downregulation of S1pr1 is required for the establishment of resident memory CD8 ${ }^{+}$T cells. Nat Immunol 14: 1285-1293. doi:10 $.1038 /$ ni.2745

Slütter B, Van Braeckel-Budimir N, Abboud G, Varga SM, Salek-Ardakani S, Harty JT. 2017. Dynamics of influenzainduced lung-resident memory $\mathrm{T}$ cells underlie waning heterosubtypic immunity. Sci Immunol 2: eaag2031. doi:10.1126/sciimmunol.aag2031

Smith-Garvin JE, Burns JC, Gohil M, Zou T, Kim JS, Maltzman JS, Wherry EJ, Koretzky GA, Jordan MS. 2010. T-cell receptor signals direct the composition and function of the memory $\mathrm{CD}^{+}$T-cell pool. Blood 116: 5548-5559. doi:10.1182/blood-2010-06-292748

Sowell RT, Rogozinska M, Nelson CE, Vezys V, Marzo AL. 2014. Cutting edge: generation of effector cells that localize to mucosal tissues and form resident memory CD8 T cells is controlled by mTOR. J Immunol 193: 2067-2071. doi:10.4049/jimmunol.1400074

Stark R, Wesselink TH, Behr FM, Kragten NAM, Arens R, Koch-Nolte F, van Gisbergen KPJM, van Lier RAW. 2018. $\mathrm{T}_{\mathrm{RM}}$ maintenance is regulated by tissue damage via

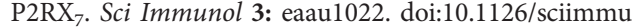
nol.aau1022

Steinbach K, Vincenti I, Kreutzfeldt M, Page N, Muschaweckh A, Wagner I, Drexler I, Pinschewer D, Korn T, Merkler D. 2016. Brain-resident memory T cells represent an autonomous cytotoxic barrier to viral infection. J Exp Med 213: 1571-1587. doi:10.1084/jem.20151916

Steinert EM, Schenkel JM, Fraser KA, Beura LK, Manlove LS, Igyártó BZ, Southern PJ, Masopust D. 2015. Quantifying memory CD8 T cells reveals regionalization of immunosurveillance. Cell 161: 737-749. doi:10.1016/j.cell.2015.03 .031

Stelekati E, Shin H, Doering TA, Dolfi DV, Ziegler CG, Beiting DP, Dawson L, Liboon J, Wolski D, Ali MAA, et al. 2014. Bystander chronic infection negatively impacts development of $\mathrm{CD} 8^{+} \mathrm{T}$ cell memory. Immunity 40: 801813. doi:10.1016/j.immuni.2014.04.010

Stemberger C, Huster KM, Koffler M, Anderl F, Schiemann $\mathrm{M}$, Wagner H, Busch DH. 2007. A single naive $\mathrm{CD}^{+}{ }^{+} \mathrm{T}$ cell precursor can develop into diverse effector and memory subsets. Immunity 27: 985-997. doi:10.1016/j .immuni.2007.10.012

Storch J, Thumser AE. 2010. Tissue-specific functions in the fatty acid-binding protein family. $J$ Biol Chem 285: 32679-32683. doi:10.1074/jbc.R110.135210

Szabo PA, Miron M, Farber DL. 2019. Location, location, location: tissue resident memory $\mathrm{T}$ cells in mice and humans. Sci Immunol 4: eaas9673. doi:10.1126/sciimmunol .aas 9673

Travis MA, Sheppard D. 2014. TGF- $\beta$ activation and function in immunity. Annu Rev Immunol 32: 51-82. doi:10 .1146/annurev-immunol-032713-120257 van Gisbergen KP, Kragten NA, Hertoghs KM, Wensveen FM, Jonjic S, Hamann J, Nolte MA, van Lier RA. 2012. Mouse Hobit is a homolog of the transcriptional repressor Blimp-1 that regulates NKT cell effector differentiation. Nat Immunol 13: 864-871. doi:10.1038/ni .2393

Vieira Braga FA, Hertoghs KML, Kragten NAM, Doody GM, Barnes NA, Remmerswaal EBM, Hsiao CC, Moerland PD, Wouters D, Derks IAM, et al. 2015. Blimp-1 homolog Hobit identifies effector-type lymphocytes in humans. Eur J Immunol 45: 2945-2958. doi:10.1002/eji 201545650

Wakim LM, Woodward-Davis A, Bevan MJ. 2010. Memory $\mathrm{T}$ cells persisting within the brain after local infection show functional adaptations to their tissue of residence. Proc Natl Acad Sci 107: 17872-17879. doi:10.1073/pnas .1010201107

Wakim LM, Woodward-Davis A, Liu R, Hu Y, Villadangos J, Smyth G, Bevan MJ. 2012. The molecular signature of tissue resident memory $\mathrm{CD} 8 \mathrm{~T}$ cells isolated from the brain. J Immunol 189: 3462-3471. doi:10.4049/jimmu nol.1201305

Wakim LM, Smith J, Caminschi I, Lahoud MH, Villadangos JA. 2015. Antibody-targeted vaccination to lung dendritic cells generates tissue-resident memory CD8 T cells that are highly protective against influenza virus infection. Mucosal Immunol 8: 1060-1071. doi:10.1038/mi.2014 .133

Wang B, Wu S, Zeng H, Liu Z, Dong W, He W, Chen X, Dong X, Zheng L, Lin T, et al. 2015. CD103 ${ }^{+}$tumor infiltrating lymphocytes predict a favorable prognosis in urothelial cell carcinoma of the bladder. J Urol 194: 556-562. doi:10.1016/j.juro.2015.02.2941

Watanabe R, Gehad A, Yang C, Scott LL, Teague JE, Schlapbach C, Elco CP, Huang V, Matos TR, Kupper TS, et al. 2015. Human skin is protected by four functionally and phenotypically discrete populations of resident and recirculating memory T cells. Sci Transl Med 7: 279ra39. doi:10.1126/scitranslmed.3010302

Webb JR, Milne K, Watson P, Deleeuw RJ, Nelson BH. 2014. Tumor-infiltrating lymphocytes expressing the tissue resident memory marker CD103 are associated with increased survival in high-grade serous ovarian cancer. Clin Cancer Res 20: 434-444. doi:10.1158/1078-0432 .CCR-13-1877

Williams MA, Bevan MJ. 2007. Effector and memory CTL differentiation. Annu Rev Immunol 25: 171-192. doi:10 $.1146 /$ annurev.immunol.25.022106.141548

Workel HH, Komdeur FL, Wouters MCA, Plat A, Klip HG, Eggink FA, Wisman GBA, Arts HJG, Oonk MHM, Mourits MJE, et al. 2016. CD103 defines intraepithelial CD8 ${ }^{+}$ $\mathrm{PD}^{+}$tumour-infiltrating lymphocytes of prognostic significance in endometrial adenocarcinoma. Eur J Cancer 60: 1-11. doi:10.1016/j.ejca.2016.02.026

Wu T, Hu Y, Lee YT, Bouchard KR, Benechet A, Khanna K, Cauley LS. 2014. Lung-resident memory CD8 T cells $\left(\mathrm{T}_{\mathrm{RM}}\right)$ are indispensable for optimal cross-protection against pulmonary virus infection. J Leukoc Biol 95: 215-224. doi:10.1189/jlb.0313180

Zaid A, Mackay LK, Rahimpour A, Braun A, Veldhoen M, Carbone FR, Manton JH, Heath WR, Mueller SN. 2014 Persistence of skin-resident memory $\mathrm{T}$ cells within an 


\section{F.E. Dijkgraaf et al.}

epidermal niche. Proc Natl Acad Sci 111: 5307-5312. doi:10.1073/pnas.1322292111

Zaid A, Hor JL, Christo SN, Groom JR, Heath WR, Mackay LK, Mueller SN. 2017. Chemokine receptor-dependent control of skin tissue-resident memory T cell formation. $J$ Immunol 199: 2451-2459. doi:10.4049/jimmunol.1700571

Zehn D, Lee SY, Bevan MJ. 2009. Complete but curtailed Tcell response to very low-affinity antigen. Nature 458 : 211-214. doi:10.1038/nature07657
Zens KD, Chen JK, Guyer RS, Wu FL, Cvetkovski F, Miron M, Farber DL. 2017. Reduced generation of lung tissueresident memory T cells during infancy. J Exp Med 214: 2915-2932. doi:10.1084/jem.20170521

Zhang N, Bevan MJ. 2013. Transforming growth factor- $\beta$ signaling controls the formation and maintenance of gut-resident memory $\mathrm{T}$ cells by regulating migration and retention. Immunity 39: 687-696. doi:10.1016/j .immuni.2013.08.019 


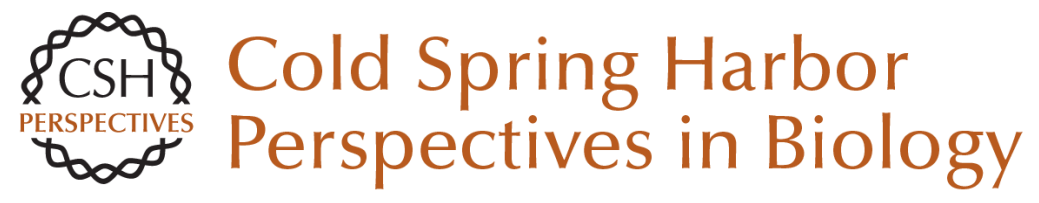

\section{Formation of Tissue-Resident CD8+ T-Cell Memory}

Feline E. Dijkgraaf, Lianne Kok and Ton N.M. Schumacher

Cold Spring Harb Perspect Biol 2021; doi: 10.1101/cshperspect.a038117 originally published online March 8, 2021

\section{Subject Collection T-Cell Memory}

Defining the Molecular Hallmarks of T-Cell

Memory

Caitlin C. Zebley, Rama S. Akondy, Benjamin A. Youngblood, et al.

Evolving Views of Long Noncoding RNAs and Epigenomic Control of Lymphocyte State and Memory

Tasha A. Morrison, William H. Hudson, Danielle A. Chisolm, et al.

Temporal and Epigenetic Control of Plasticity and Fate Decision during CD8 + T-Cell Memory

Differentiation Luigia Pace

Durable CD4 T-Cell Memory Generation Depends on Persistence of High Levels of Infection at an Effector Checkpoint that Determines Multiple Fates

Susan L. Swain, Michael C. Jones, Priyadharshini Devarajan, et al.

Decoding Tissue-Residency: Programming and Potential of Frontline Memory T Cells Simone L. Park and Laura K. Mackay

A Single-Cell Perspective on Memory T-Cell Differentiation

Lorenz Kretschmer, Dirk H. Busch and Veit R. Buchholz
Transcriptional Control of Cell Fate Determination in Antigen-Experienced CD8 T Cells

Shanel Tsuda and Matthew E. Pipkin

CD4+ Memory T-Cell Formation during Type 1 Immune Responses

Peter D. Krueger, Kevin C. Osum and Marc K. Jenkins

CD8 + T-Cell Memory: The Why, the When, and the How

Stephen J. Turner, Taylah J. Bennett and Nicole L. La Gruta

How to Reliably Define Human CD8+ T-Cell

Subsets: Markers Playing Tricks

Michiel C. van Aalderen, Rene A.W. van Lier and

Pleun Hombrink

Memory T-Cell Heterogeneity and Terminology Yuki Muroyama and E. John Wherry

Homeostasis of Naive and Memory T

Lymphocytes

Takeshi Kawabe, Jaeu Yi and Jonathan Sprent

For additional articles in this collection, see http://cshperspectives.cshlp.org/cgi/collection/

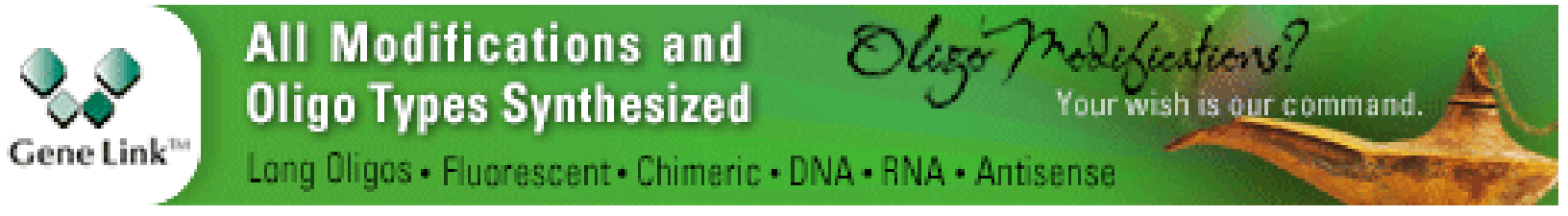

Copyright @ 2021 Cold Spring Harbor Laboratory Press; all rights reserved 


\section{Formation of Tissue-Resident CD8 ${ }^{+} \mathrm{T}$-Cell Memory}

Feline E. Dijkgraaf, Lianne Kok and Ton N.M. Schumacher

Homeostasis and Durability of T-Cell Memory-The Resting and the Restless T-Cell Memory Andreas Radbruch, Mairi Anne McGrath, Francesco Siracusa, et al.
Motility Matters: How CD8+ T-Cell Trafficking Influences Effector and Memory Cell

Differentiation

Yagmur Farsakoglu, Bryan McDonald and Susan M. Kaech

A Regenerative Perspective on Successful and Failed T-Cell Immunity Steven L. Reiner

For additional articles in this collection, see http://cshperspectives.cshlp.org/cgi/collection/

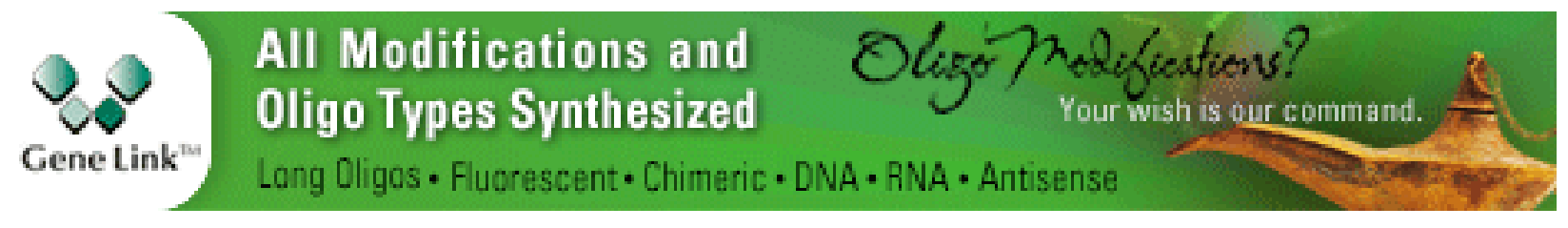

Copyright @ 2021 Cold Spring Harbor Laboratory Press; all rights reserved 